Draft for Review - 03/10/97

\title{
Radiotoxicity of Neptunium(V) and Neptunium(V) - Nitrilotriacetic (NTA) Acid Complexes \\ Towards Chelatobacter heintzii
}

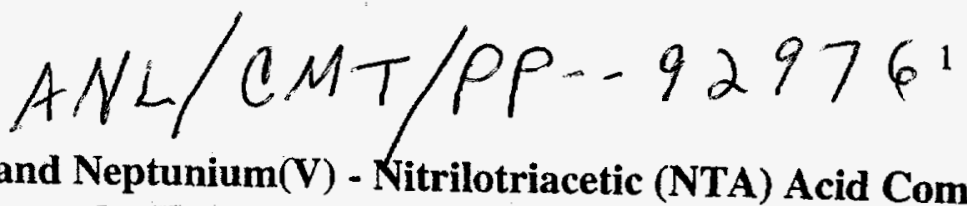

\author{
James E. Banaszak ${ }^{a, b}$ \\ Donald T. Reed ${ }^{b^{*}}$ \\ Bruce E. Rittmann ${ }^{\mathrm{a}}$

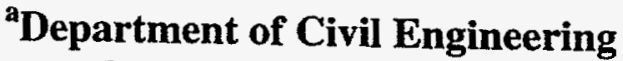 \\ Northwestern University \\ 2145 Sheridan Road \\ Evanston, IL 60208-3109 \\ ${ }^{b}$ Chemical Technology Division \\ Argonne National Laboratory \\ 9700 South Cass Avenue \\ Argonne, IL 60439

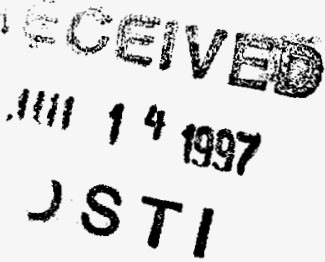

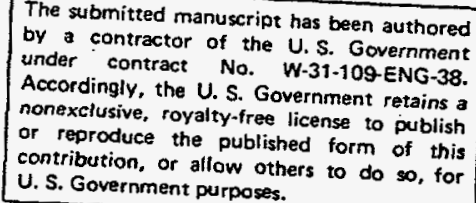

\section{DISCLAIMER}

This report was prepared as an account of work sponsored by an agency of the United States Government. Neither the United States Government nor any agency thereof, nor any of their employees, makes any warranty, express or implied, or assumes any legal liability or responsibility for the accuracy, completeness, or usefulness of any information, apparatus, product, or process disclosed, or represents that its use would not infringe privately owned rights. Reference herein to any specific commercial product, process, or service by trade name, trademark, manufacturer, or otherwise does not necessarily constitute or imply its endorsement, recommendation, or favoring by the United States Government or any agency thereof. The views and opinions of authors expressed herein do not necessarily state or reflect those of the United States Government or any agency thereof.

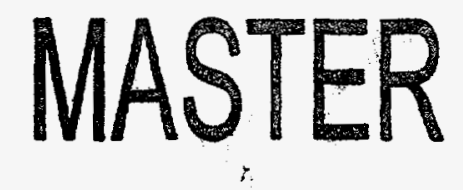




\section{DISCLAMMER}

Portions of this document may be illegible in electronic image products. Images are produced from the best available original document. 
Radiotoxicity of Neptunium(V) and Neptunium(V) - Nitrilotriacetic Acid (NTA) Complexes Towards Chelatobacter heintzii

\author{
James E. Banaszak ${ }^{1,2}$ \\ Donald T. Reed ${ }^{2 *}$ \\ Bruce E. Rittmann ${ }^{1}$ \\ ${ }^{1}$ Department of Civil Engineering \\ Northwestern University \\ 2145 Sheridan Road \\ Evanston, IL 60208-3109 \\ ${ }^{2}$ Chemical Technology Division \\ Argonne National Laboratory \\ 9700 South Cass Avenue \\ Argonne, IL 60439 \\ *Corresponding author \\ e-mail: reedd@cmt.anl.gov \\ phone: $630-252-7964$ \\ fax: $630-252-4176$
}

\begin{abstract}
\end{abstract}
The objective of this work was to investigate the toxicity mechanisms of neptunium and the neptunium-NTA complex towards Chelatobacter heintzii. Our results show that metal toxicity of aquo $\mathrm{NpO}_{2}{ }^{+}$may significantly limit growth of $C$. heintzii at free metal ion concentrations greater than $\approx 10^{-5} \mathrm{M}$. However, neptunium concentrations $\geq 10^{-4} \mathrm{M}$ do not cause measurable radiotoxicity effects in $C$. heintzii when present in the form of a neptunium-NTA complex or colloida/precipitated neptunium-phosphate. The neptunium-

7 NTA complex, which is stable under aerobic conditions, is destabilized by microbial degradation of NTA. When phosphate was present, degradation of NTA led to the 9 precipitation of an neptunium-phosphate phase. 


\section{Introduction}

Past practices at U.S. Department of Energy (DOE) facilities have resulted in the contamination of subsurface aquifers with mixtures of organic compounds and radionuclides. An important class of mixed contaminants includes co-disposed actinides and organic chelating agents, such as nitrilotriacetic acid (NTA) (27). The presence of strong complexing agents in subsurface environments can increase dissolved actinide concentrations, leading to enhanced radionuclide migration in groundwater (20).

The extent of NTA-induced migration depends on the long-term stability of the actinidechelate complex. It has recently become clear that microorganisms play an important role in subsurface environmental chemistry (4). Microbial activities affect the concentration of biodegradable compounds and redox conditions in subsurface aquifers. Furthermore, microbial degradation of primary substrates in many cases produces or consumes acid equivalents, lowering or raising system $\mathrm{pH}$ (28). Therefore, the chemical speciation of redox and acid/base sensitive compounds in groundwaters can be largely dependent on biological activities.

NTA is utilized by some bacteria, including Chelatobacter heintzii, as a sole source of carbon, nitrogen, and energy (8). Degradation of NTA by microorganisms decreases chelate availability, which modifies the speciation of metals and actinides in the system (3). The actinide species may form a complex with other ligands in the system; sorb onto oxides, organic matter surfaces, or bacteria cell membranes; or precipitate from solution (13, 29).

The speciation of actinides in the subsurface, subsequent to the microbiological degradation of the organic complexant, is defined by the inorganic (e.g., phosphate, carbonate, hydroxy) and organic (humic/fulvic acids) anions present, as well as $\mathrm{pH}$. Of particular relevance to this paper. phosphates control metal solubility in some subsurface environments (30). 
Morgenstern and Kim (22) determined formation constants for phosphate complexation with

$\mathrm{Np}(\mathrm{V})$ and used chemical equilibrium calculations to predict that neptunium-phosphate

complexation dominates carbonate complexation at phosphate concentrations $\geq 10^{-4} \mathrm{M}$.

Bioprecipitation of uranium as a phosphate phase was linked to phosphatase-enzyme activity in a Citrobacter sp, suggesting that biologically mediated phosphate precipitation may be an effective method of removing actinides from contaminated waters (14-16).

Radioactive elements, such as actinides, are unique because they are potentially toxic to microorganisms via two distinct mechanisms. First, actinide species can be chemically toxic, similar to other metals. The uncomplexed metal ions are usually more toxic to microorganisms than complexed metal species $(1,6,11,17)$. Neptunium may inhibit growth in the same manner as other metals, for example by binding with proteins necessary for substrate transport or by substitution into cofacter metal ion sites (6). Second, microorganisms are susceptible to toxic effects caused by the ionizing radiation emitted during radioactive decay $(9,18,34)$. Ionizing radiation induces toxicity by causing unrepairable cell damage that prevents cell reproduction or causes cell death via several potential pathways. Reed (26) found that radiotoxicity effects of plutonium were induced below the absorbed dose threshold due to intimate association of the plutonium with $C$. heintzii. Neptunium, primarily an alpha particle emitter (10), is potentially toxic to microorganisms if alpha particles emitted interact directly with the cell when the radionuclide is ingested by the organism during metabolic processes (34), is present in high enough concentrations to apply overall radiation doses exceeding the organism's radiation threshold (9), or is sorbed extracellularly (26).

As part of our continuing investigations of the interactions between actinide species and microorganisms, the objective of this work was to explore the potential toxicity mechanisms of 
neptunium towards $C$. heintzii and establish the stability of the neptunium-NTA complex in the presence of aerobic microbiological activity. We found that only the free $\mathrm{NpO}_{2}{ }^{+}$ion inhibited growth of $C$. heint:ii and that the toxic effects were mitigated when neptunium was complexed with NTA or phosphate or was bound in a neptunium-phosphate colloid/precipitate.

\section{METHODS AND MATERIALS}

Aquo $\mathrm{NpO}_{2}{ }^{+}$ion toxicity was determined by growing $C$. heintzii in a fixed-pH glucose media with various neptunium concentrations. The glucose minimal media was used to prevent significant complexation with neptunium. Growth in the glucose media was intentionally nutrient limited to measure potential short-term toxicity effects.

In order to determine the stability of the neptunium-NTA complex and the potential radiotoxicity of neptunium-NTA towards $C$. heintzii, variable-pH experiments were conducted in a defined mineral salts NTA growth medium and with varying neptunium concentrations. Growth- medium speciation during NTA degradation was computed using the dynamic chemical equilibrium computer code, CCBATCH (see Appendix A for a brief description of $\mathrm{CCBATCH}$ and the modeling methodology used for this work), developed at Northwestern University for the study of coupled chemical and biological processes (28). Chemical equilibrium calculations indicated that the initial dominant neptunium speciation in the medium was $63 \% \mathrm{NpO}_{2} \mathrm{NTA}^{2-}, 24$ $\% \mathrm{NpO}_{2} \mathrm{HPO}_{4}-10 \% \mathrm{NpO}_{2}{ }^{+}$and $2 \% \mathrm{NpO}_{2} \mathrm{PO}_{4}{ }^{2-}$. Absorption spectroscopy verified that $\mathrm{NpO}_{2} \mathrm{NTA}^{2-}(990.2 \mathrm{~nm})$ was the predominant neptunium species. $\mathrm{NpO}_{2} \mathrm{PO}_{4}{ }^{2-}(988.8 \mathrm{~nm})$ could not be initially identified spectroscopically due to peak convolution with $\mathrm{NpO}_{2} \mathrm{NTA}^{2-}$. Growth in the NTA experiments was limited only by the amount of NTA available as a primary substrate. Initial cell inoculations and total neptunium concentrations for both sets of experiments are detailed in Table 1. 
79 Sample preparation. Chelatobacter heintzii (ATCC 29600), an obligately aerobic NTA degrader, was grown in a defined NTA culture media (31) consisting of the following mineral additions (in gm per $\mathrm{L}$ ): $\mathrm{K}_{2} \mathrm{HPO}_{4}, 1.606 ; \mathrm{KH}_{2} \mathrm{PO}_{4}, 0.403 ; \mathrm{NH}_{4} \mathrm{NO}_{3}, 0.499 ; \mathrm{MgSO}_{4} \bullet 7 \mathrm{H}_{2} \mathrm{O}, 0.203$; $\mathrm{CaCl}_{2} \bullet 2 \mathrm{H}_{2} \mathrm{O} .0 .0200 ; \mathrm{FeCl}_{3} \bullet 6 \mathrm{H}_{2} \mathrm{O}, 0.0027$; NTA, 0.999; and $\mathrm{NaOH}$ to adjust was the $\mathrm{pH}$ to 7.0

$83 \pm 0.1$. Growing cells were harvested in the log phase of growth $\left(600 \mathrm{~nm}\right.$ Optical Density $\left(\mathrm{OD}_{600}\right)$

$\approx 0.1)$; "resting" cells were harvested in post-log phase $\left(\mathrm{OD}_{600}>0.1\right)$. Cells were rinsed three times in pH 6.2 \pm 0.1 0.01 M PIPES (Piperazine-N, N'-bis[2-ethanesulfonic acid]) solution, concentrated by centrifugation, and re-suspended in 0.01 M PIPES solution to prepare an inoculum with a final $\mathrm{OD}_{600}$ of $0.4-0.6$.

Sterile neptunium-NTA sample vessels were prepared by adding incremental amounts of $\geq 95 \%$ isotopic purity ${ }^{237} \mathrm{~Np}$ stock solution, filtered through a $0.2-\mu \mathrm{m}$ membrane filter, to defined mineral media in 30-ml serum bottles. Three control samples were prepared in a similar manner without addition of neptunium. All samples were inoculated with the culture described above.

Neptunium-glucose experiments were conducted in a minimal glucose growth medium to prevent neptunium-organic complexation. The medium was prepared by addition of $0.942 \mathrm{gm} / 1$ glucose (dextrose) to a $0.01 \mathrm{M}$ PIPES solution. The final $\mathrm{pH}$ of the solution was adjusted to $6.0 \pm$ 0.1 before $0.2-\mu \mathrm{m}$ membrane filter sterilization. Aquo $\mathrm{Np}(\mathrm{V})$ samples were then prepared by adding incremental amounts of sterile neptunium stock. All growth experiments were performed in the dark at room temperature $\left(21 \pm 2^{\circ} \mathrm{C}\right)$ under aerobic conditions.

Sample analysis. 1-ml aliquots were periodically drawn from each vessel and analyzed for biomass production and neptunium-NTA complex stability by measuring the visible light-near infra red (VIS-NIR) absorption spectrum from 575 to $1250 \mathrm{~nm}$ using a Varian CARY 5 
spectrophotometer. A $0.2-\mathrm{ml}$ subsample was then drawn from each aliquot and added to $10 \mathrm{ml}$

102 of Lltima Gold scintillation cocktail (Packard); another 0.1 -ml subsample was added to $0.9 \mathrm{ml}$ of sterile, deionized water. The remainder of the aliquot was filtered through a $0.2-\mu \mathrm{m}$ filter, and particle scintillation counts between the unfiltered and filtered samples. All counting was done with a Packard model 2500 TR liquid scintillation analyzer.

The long term viability of $C$. heintzii in the presence of neptunium was monitored by dilution by the addition of $0.1 \mathrm{ml}$ of unfiltered sample to $0.9 \mathrm{ml}$ deionized water, and via recomplexation by addition of $0.1 \mathrm{ml}$ of unfiltered sample to $0.9 \mathrm{ml}$ of 0.001 M NTA solution. Colony Forming Unit (CFU) plate counts. The ten-fold diluted subsamples described above were used to prepare serial dilutions up to $10^{-8}: 1$. Two $25 \mu \mathrm{l}$ splits from each dilution were spread onto $6 \%$ Agar-NTA growth media culture plates and observed for colony formation. Extraction of particulate-associated neptunium was determined by two methods: via Colloidal/precipitate neptunium-phosphate characterization was performed by measuring

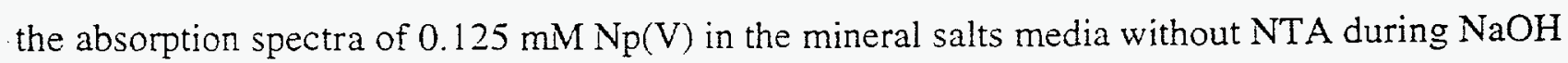
titration. A similar procedure was completed on a $0.125 \mathrm{mM} \mathrm{Np}(\mathrm{V})-20 \mathrm{mM} \mathrm{H} \mathrm{PO}_{4}$ solution for comparison. $\mathrm{NpO}_{2} \mathrm{PO}_{4}{ }^{2-}$ and $\mathrm{NpO}_{2} \mathrm{HPO}_{4}$ species were characterized by comparison with their known absorption bands (22).

Samples for NTA concentration analysis were prepared by adding $0.2 \mathrm{ml}$ of $0.2-\mu \mathrm{m}$

123 Ion Chromatograph (IC). The IC was calibrated using freshly prepared NTA standards. NTA 
Draft for Review - 03/10/97

124 peak location was veritied after sample analysis by spiking one sample with additional NTA and 125 re-analyzing.

126

127

128

129

130

131

132

\section{RESULTS AND DISCLSSION}

\section{Neptunium toxicity and stability towards Chelatobacter heintzii in glucose growth media.}

Neptunium-glucose experiments were run at two different initial cell densities to determine if potential $\mathrm{Np}(\mathrm{V})$ toxicity was related to cell concentration. Microbial growth was tracked for all samples for 40 days. Figure la shows that $\mathrm{NpO}_{2}^{+}$concentrations of $5 \times 10^{-5} \mathrm{M}$ rapidly inhibited the growth of $C$. heintzii independent of initial cell density. A smaller inhibitory effect was observed from lower neptunium concentrations after 10 days. Plate counts of resting cells in the presence of $2.5 \times 10^{-4} \mathrm{M} \mathrm{NpO}_{2}^{+}$showed a 50\% loss in viability after 1 day (data not shown), and $\mathrm{OD}$ measurements (Figure $\mathrm{lb}$ ) indicated that this concentration of $\mathrm{NpO}_{2}{ }^{+}$caused complete inhibition within 200 hours. Although the exact mechanism responsible for growth inhibition can not be conclusively discerned from these data, the rapid onset of growth inhibition at $\mathrm{NpO}_{2}^{+}$ concentrations $>5 \times 10^{-5} \mathrm{M}$ suggests that neptunium inhibition is chemical rather than radiolytic in nature, since the damage caused by ionizing radiation is a function of the absorbed radiation dose, a time-dependent parameter.

Neptunium partitioning between aqueous and particulate phases was monitored in these experiments by absorption spectrometry and alpha scintillation counting of unfiltered vs $0.2-\mu \mathrm{m}$ filtered samples. The $\mathrm{NpO}_{2}{ }^{+}$concentrations determined from VIS-NIR spectrometry shown in Figure 2 indicate that the $\mathrm{Np}(\mathrm{V})$ concentration was stable over the course of the experiment. However, scintillation counting showed that 0 to $20 \%$ of the ${ }^{237} \mathrm{~Np}$ was associated with the particulate phase (data not shown). Since the most significant partitioning was measured in samples with high neptunium and biomass concentrations, we believe that the scintillation 
$1+7$

$1+8$

149

150

151

152

153

154

155

156

157

158

partitioning results are an artifact of the filtration procedure. rather than an indication of

significant biosorption. We would not expect biosorption to be a significant mechanism in the $\mathrm{Np}(\mathrm{V})$ system, since $\mathrm{NpO}_{2}{ }^{+}$sorption on organic surfaces is much less significant than that of $\mathrm{Np}(\mathrm{IV})$, due to the large difference in charge between the two ions (29).

Stability of the Np-NTA complex during NTA degradation. The growth rate of $C$. heintzii in NTA mineral media could be expected to be adversely affected by the presence of neptunium in two ways. Because NTA is a strong chelator, most neptunium in solution will form a neptuniumNTA complex, effectively rendering a portion of the NTA unavailable for biological utilization. However, chemical equilibrium speciation calculations predict that even the highest concentration neptunium sample could only complex with $\approx 2 \%$ of the initial NTA in solution. Thus, the concentration-dependent growth rate of $C$. heintzii should remain unaffected by the amount of neptunium present in these experiments, as long as sufficient excess NTA is present. The second possible mechanism that could affect the biological growth rate is the potential toxicity of neptunium towards $C$. heintzii, either as a result of metal toxicity (free ion) or due to radiolytic (free or complexed neptunium) effects. Results from the neptunium-glucose experiments showed that significant metal toxicity would not be expected unless the concentration of the free $\mathrm{Np}(\mathrm{V})$ released from the NTA complex exceeded $5 \times 10^{-5} \mathrm{M}$. In order to isolate potential radiotoxicity effects from neptunium chemical toxicity, the minimum starting NTA:neptunium ratio for these experiments was 50:1. Chemical speciation calculations indicated that the highest free $\mathrm{NpO}_{2}{ }^{+}$concentration was $1.3 \times 10^{-5} \mathrm{M}$ under the initial conditions; therefore, the chemical toxicity effects from the free ion should have been small.

Figure 3 shows the growth of $C$. heintzii in NTA mineral media in the presence of increasing neptunium concentrations. Growth appeared to be unaffected by neptunium 
concentrations up to $10^{-4} \mathrm{M}$, a result verified by viable plate counts taken during the course of the experiments: Culture plates prepared after 45 days showed that cells grown in the presence of $10^{-4} \mathrm{M}$ neptunium had similar colony numbers to the control samples, suggesting that radiotoxicity was not important at this concentration. The dose-to-solution at the highest neptunium concentration is well below the lethal external radiation dose for C. heintzii, $330 \mathrm{~Gy}$ (33 Krad) (26): At a neptunium concentration of $1.25 \times 10^{-4} \mathrm{M}$, the effective ionizing radiation dose is $\approx 0.05 \mathrm{~Gy}(5 \mathrm{rad})$ per day, or approximately $2.5 \mathrm{~Gy}(0.25 \mathrm{Krad})$ over the course of the 48 day experiment. to preferential association of $\mathrm{Pu}(\mathrm{IV})$ with the biomass, were observed at radiation doses below the lethal dose. Figure 4 shows the amount of neptunium associated with $C$. heintzii, as determined by $\alpha$-particle scintillation counting of $0.2-\mu \mathrm{m}$ filtered vs. unfiltered samples. Partitioning to the solid phase was negligible for the first 250 hours, but then rapidly increased. Figure 5 illustrates that, at the end of the experiment, the amount of neptunium in the filtrate was roughly proportional to the total neptunium concentration in solution.

Although Pu(IV) associated with $C$. heintzii cells was not readily extractable with EDTA (26), $0.001 \mathrm{M} N \mathrm{NA}$ recovered $97 \%$ of the neptunium from the particulate fraction, verifying that the particulate neptunium was nearly completely recoverable. Approximately $41 \%$ of the particle-associated neptunium was extracted by 10 -fold dilution with deionized water of one of the $10^{-4} \mathrm{M}$ neptunium samples. The resulting particulate neptunium was $55 \%$, which corresponds with the measured particulate neptunium in the $10^{-5} \mathrm{M}$ neptunium sample. 
192 short time frame of the extraction procedure, indicating that the free $\mathrm{Np}(\mathrm{V})$ ion concentration was

193 reaching chemical equilibrium with the particulate fraction.

194 Neptunium Speciation During Glucose and NTA Biodegradation. Reversible, concentrationdependent partitioning and lack of microbial growth inhibition suggest that neptunium released from the NTA complex was being scavenged by other ligands in the system, making it unavailable to $C$. heintzii. Subsequent colloid formation or precipitation would explain neptunium association with the biomass. In order to determine the mechanism responsible for mitigating the potential toxicity of neptunium released from NTA complexation, chemical equilibrium modeling was combined with spectrophotometric investigations to establish the changing chemical speciation of neptunium in the growth media during NTA degradation. VIS-NIR spectrometry during the glucose media experiments verified that the $N p(V)$ oxidation state is stable at neutral $\mathrm{pH}$ in the presence of $C$. heintzii. The stability of the $\mathrm{Np}(\mathrm{V})$ NTA complex was monitored by periodically measuring the absorption spectrum during NTA degradation by $C$. heintzii. Figure 6 compares spectra from a $1.25 \times 10^{-4} \mathrm{M}$ neptunium-NTA sample after 2 hours and 3,4,6 and 48 days of growth. The complex was initially stable in the presence of biological activity for up to 6 days. Loss of the neptunium-NTA complex from solution at 48 days is reflected by the disappearance of the absorption band at $990.2 \mathrm{~nm}$. following NTA degradation by $C$. heintzii. First, free $\mathrm{NpO}_{2}{ }^{+}$may have been adsorbed onto the cell membrane, as is seen in the Pu system. However, results from glucose-media experiments suggested that biosorption of neptunium is not a significant process. An alternative explanation is that neptunium released from the NTA complex could have formed a solid phase if NTA degradation by $C$. heintzii changed the solution characteristics such that neptunium precipitation 
215 became favorable. Figure 7 shows an enlargement of the 48 day spectrum of the unfiltered $10^{-4}$

216 M neptunium sample shown in Figure 6. The unfiltered spectrum shows a new band formation

217 at $\approx 1015 \mathrm{~nm}$, which is indicative of the formation of a new neptunium species.

218 Precipitate formation should be correlated with the loss of NTA from solution, since

219 excess NTA would lead to a stable NTA complex. The small 990-nm peak for a filtered sample,

220 shown in the inset of Figure 7, corresponded with the final concentration of NTA at the end of

221 the experiment, shown in Table 2, and the maximum amount of neptunium that could be complexed by NTA. All samples showed nearly complete NTA degradation, verifying that neptunium speciation was no longer being dominated by NTA complexation.

The $1015 \mathrm{~nm}$ peak observed in Figures 6 and 7 has not been previously reported for

$\mathrm{Np}(\mathrm{V})$ VIS-NIR absorption spectra. However, carbonate and phosphate complexation with

in groundwater as a byproduct of organic degradation and as a result of mineral dissolution, and is a strong actinide complexant that can affect actinide mobility in subsurface aquifers (5). Neptunium solubility in many carbonate systems is controlled by a $\mathrm{Me}(\mathrm{I}) \mathrm{NpO}_{2} \mathrm{CO}_{3}$ precipitate, where $\mathrm{Me}(\mathrm{I})$ represents any mono-valent cation. Using a representative solubility product of $10^{-10.28}(24)$, the expected $\mathrm{NpO}_{2}{ }^{+}$concentration in equilibrium with a $\mathrm{Me}(\mathrm{I}) \mathrm{NpO}_{2} \mathrm{CO}_{3}$ solid, $0.1 \mathrm{M}$ $\mathrm{Me}(\mathrm{I})$, and atmospheric $\mathrm{CO}_{2}(\mathrm{~g})$ at $\mathrm{pH} 8$, the highest final $\mathrm{pH}$ of the growth media after NTA degradation, would be $\approx 2.6 \times 10^{-4} \mathrm{M}$. All the final measured $\mathrm{NpO}_{2}^{+}$concentrations shown in

Table 2 were below this level, suggesting that neptunium solubility was being controlled by another solid phase. 
338 waters when phosphate concentrations exceed $10^{-1} \mathrm{M}$. Although phosphate solid phases have been characterized for some actinide systems, no solubility data are available for the Np(V)phosphate system.

To predict the dominant neptunium complexes in the system, we used the computer program $\mathrm{CCBATCH}$ to simulate the equilibrium chemical speciation of the mineral growth media during NTA degradation by $C$. heintzii. The aerobic biodegradation of NTA can be described by the following stoichiometry when $\mathrm{HNTA}^{2-}$ is selected as the degradable form of $\operatorname{NTA}(3,28)$ :

$$
\begin{aligned}
0.055 \mathrm{C}_{6} \mathrm{H}_{7} \mathrm{O}_{6} \mathrm{~N}^{2-}+0.0875 \mathrm{O}_{2}+0.133 \mathrm{H}^{+}+0.069 \mathrm{H}_{2} \mathrm{O} \rightarrow \\
0.032 \mathrm{C}_{5} \mathrm{H}_{7} \mathrm{O}_{2} \mathrm{~N}+0.17 \mathrm{H}_{2} \mathrm{CO}_{3}+0.023 \mathrm{NH}_{4}^{+}
\end{aligned}
$$

247 where $\mathrm{C}_{5} \mathrm{H}_{7} \mathrm{O}_{2} \mathrm{~N}$ represents biomass.

Inspection of the reaction stoichiometry explains the $\mathrm{pH}$ rise observed in weakly buffered systems undergoing NTA degradation. Each mole of HNTA ${ }^{2-}$ degraded consumes 2.4 acid equivalents, causing the rise in $\mathrm{pH}$. The magnitude of this effect depends on the concentration of 251 other buffers in the system and may also be mitigated by retention in solution of a portion of the 3.4 moles of carbonic acid produced per mole of NTA degraded. For example, in a closed system, carbonic acid retention causes a less dramatic $\mathrm{pH}$ increase as compared to a solution in equilibrium with atmospheric $\mathrm{CO}_{2}(\mathrm{~g})$. Additionally, precipitation of $\mathrm{Np}-\mathrm{CO}_{3}{ }^{2-}$ or $-\mathrm{PO}_{4}{ }^{2-}$ solids

255 would remove base equivalents from the system at near neutral $\mathrm{pH}$, which could also counter 256 increasing $\mathrm{pH}$. 
260) partial pressures $\left(10^{-3.5} \mathrm{~atm}\right)$ yielded a final $\mathrm{pH}$ prediction of 8.5 , indicating that $\mathrm{pH}$ was being 261 affected by carbonic acid retention and/or precipitation of base equivalents. Figure 8 shows the 262 predicted dominant speciation of the $0.125 \mathrm{mM} \mathrm{Np}(\mathrm{V})$-NTA mineral media solution in equilibrium with a slightly elevated $\mathrm{CO}_{2}(\mathrm{~g})$ partial pressure of $10^{-2.7}$ atm, which yielded a final predicted $\mathrm{pH}$ of 7.9. The modeling results show that $\mathrm{NpO}_{2} \mathrm{HPO}_{4}{ }_{4}$ and $\mathrm{NpO}_{2} \mathrm{PO}_{4}{ }^{2-}$ are the dominant neptunium species after significant NTA degradation has taken place. Additionally, the final $\mathrm{NpO}_{2}{ }^{+}$ion concentration calculated by the model, $1.4 \times 10^{-5} \mathrm{M}$, exceeds the final measured concentrations in Table 2 , indicating that solubility of a neptunium solid phase is limiting the amount of neptunium in solution.

Figure 9 shows the model predicted distribution of neptunium among the major complexing ligands during NTA degradation at $10^{-2.7}$ atm $\mathrm{CO}_{2}(\mathrm{~g})$ partial pressure. It illustrates that phosphate complexation accounts for $80 \%$ of the neptunium speciation in solution after $\mathrm{nm}$ peak formation with the phosphate system. In order to identify the $1015 \mathrm{~nm}$ peak, the variable-pH VIS-NIR spectra of $\mathrm{Np}(\mathrm{V})$ in the defined mineral salts media (without any NTA) was compared to the $\mathrm{Np}(\mathrm{V})$ spectra obtained in a $20 \mathrm{mM} \mathrm{H}_{3} \mathrm{PO}_{4}$ solution. The behavior of both systems followed the results seen by Morgenstern and $\mathrm{Kim}(22)$ in lower concentration phosphate solutions: Figure 10 shows that as $\mathrm{pH}$ was increased, neptunium speciation shifted from the free aquo species to successive complexation as $\mathrm{NpHPO}_{4}{ }^{-}(\approx 988 \mathrm{~nm})$ and $\mathrm{NpPO}_{4}{ }^{2-}(\approx 993 \mathrm{~nm})$. Figure 11 shows that, after $\approx 20$ minutes, new band formation at $1015 \mathrm{~nm}$ was observed at the expense of the $\mathrm{NpPO}_{+}{ }^{2-}$ complex, and the overall turbidity of both solutions increased, suggesting 281 colloid formation/precipitation. The final spectrum remained stable for days, (Figure 12), but the colloidal species had to be re-suspended in solution prior to each spectroscopic analysis. These 
results indicate that neptunium speciation after NTA degradation was controlled by the phosphate system, and neptunium-phosphate colloid formation/precipitation can be identified by VIS-NIR peak formation at $1015 \mathrm{~nm}$.

Our results correlate with work by Francis et al (11), who showed that nickel toxicity was modulated by coprecipitation of $\mathrm{Ni}$ with iron-hydroxides after citrate degradation. Also, formation of a neptunium-phosphate colloidal/precipitate phase agrees with results reported for the $\mathrm{Pu}(\mathrm{VI})$ system $(32,33)$, suggesting that phosphate colloid formation/precipitation may be an important mechanism affecting actinide solubility and speciation in natural systems. This latter finding will be investigated further, since phosphorus is a required biological nutrient and many in-situ bioremediation efforts require supplemental phosphorus additions.

Our results in this study are in contrast to previous findings in the plutonium-NTA system, where $C$. heintzii was sensitive to radiolytic effects at similar actinide concentrations due to selective association of plutonium with the biomass. This work suggests that future bioremediation efforts involving actinide elements will require careful evaluation of coupled chemical and biological processes.

\section{CONCLUSIONS}

Toxicity studies in non-complexing glucose growth media showed that aquo $\mathrm{NpO}_{2}{ }^{+}$is stable in the presence of aerobic biological activity for up to 40 days. The uncomplexed Np(V) ion significantly inhibited growth of Chelatobacter heintzii at concentrations greater than or equal to $5 \times 10^{-5} \mathrm{Mr}$, most likely due to toxic metal inhibition.

Our results show that growth of $C$. heintzii in NTA media is unaffected by the presence of up to $10^{-4} \mathrm{MIN}(\mathrm{V})$ in solution after 48 days. Viability of $C$. heint-ii remains unaffected by the presence of $10^{-4} \mathrm{M}$ neptunium after complete degradation of all NTA in solution. 
Dynamic chemical equilibrium modeling, combined with VIS-NIR absorption

307 spectrometry data, suggest that the potential toxicity of neptunium to $C$. heintzii is mitigated by

308 neptunium-phosphate precipitation induced by a pH increase caused by biodegradation of NTA.

309 ACKNOWLEDGEMENTS

310 This work was partially funded under the auspices of the DOE's Co-Contaminant

311 Chemistry Subprogram of the Subsurface Science program and Argonne National Laboratory

312 directed research funds to investigate actinide speciation in environmental systems. The

313 continued support of Dr. Frank Wobber (DOE/ER/OHER) is gratefully acknowledged. 
Dynamic chemical equilibrium modeling, combined with VIS-NIR absorption

307 spectrometry data, suggest that the potential toxicity of neptunium to $C$. heintzii is mitigated by

308 neptunium-phosphate precipitation induced by a pH increase caused by biodegradation of NTA.

309 ACKNOWLEDGEMENTS

310 This work was partially funded under the auspices of the DOE's Co-Contaminant

311 Chemistry Subprogram of the Subsurface Science program and Argonne National Laboratory

312 directed research funds to investigate actinide speciation in environmental systems. The

313 continued support of Dr. Frank Wobber (DOE/ER/OHER) is gratefully acknowledged. 
314 APPENDIX A

$315 \mathrm{CCBATCH}$ modeling methodology and application to the neptunium-NTA system.

316 CCBATCH is a computer code, developed at Northwestern University, designed to investigate

317 the dynamics of coupled biological and chemical reactions in mixed waste subsurface

318 environments. The exact modeling methodology is describe elsewhere (28). To summarize, the

319 model is unique in that it explicitly couples biological electron donor and acceptor substrate

320 consumption to competing chemical reactions in order to determine the effect of biological

321 reactions on the fate of various components in the system. Currently, the model systematically

322 considers the following competing subsurface reactions: acid/base, complexation, fixed-pH

323 precipitation, biomass synthesis and decay, substrate utilization (contaminant degradation), and 324 toxicity effects.

Based on user input information, the model calculates the equilibrium concentrations of all the chemical species in the system, including the degradable form of the electron donor substrate, at the initial $\mathrm{pH}$ and component concentrations. It uses a Newton-Raphson technique that combines the aqueous-phase mass balances with mass-action equilibrium expressions for all relevant acid/base and complexation reactions, and can it compute the equilibrium $\mathrm{pH}$ from the proton condition when the $\mathrm{pH}$ is not fixed.

Once the initial acid-base and complexation equilibria are established, the model uses the method developed by McCarty (19) to calculate the fraction of available electrons (received from the electron donor) utilized in energy generating, biomass production, and biomass decay reactions. By determining the proper rationing of electrons between these various pathways, the substrate utilization and biomass synthesis stoichiometry are calculated based on the degradable form of substrate input to the model. The correct coupling of substrate utilization to acidic 
hydrogen production or consumption is the important link that enables the model to calculate changes in system pH caused by substrate consumption.

Once the $\mathrm{pH}$ change and component total concentration adjustments are determined for a given time step, the model recalculates the acid/base and metal complex speciation of the system based on the updated component concentrations and new $\mathrm{pH}$. The newly calculated substrate concentrations are used to determine the substrate utilization rate for the next time step, and the process is repeated until the limiting substrate is exhausted. The model allows prediction of substrate utilization rates based on the concentration of individual substrate species, as opposed to overall substrate concentrations.

To illustrate the methodology used by CCBATCH, consider the fate of neptunium during the degradation of NTA, based on HNTA ${ }^{2-}$ degradation stoichiometry. The rate of change of major components in the system can be related to the rate of substrate consumption as follows:

$$
\begin{array}{ll}
\mathrm{r}_{\mathrm{HNTA}}=-\mathrm{q}_{\mathrm{md}} \frac{\mathrm{S}_{\mathrm{HNTA}}}{\mathrm{K}_{\mathrm{HNTA}}+\mathrm{S}_{\mathrm{HNTA}}} \frac{\mathrm{S}_{\mathrm{O}_{2}}}{\mathrm{~K}_{\mathrm{O}_{2}}+\mathrm{S}_{\mathrm{O}_{2}}} \mathrm{X} & \text { rate of donor utilization } \\
\mathrm{r}_{\mathrm{net}}=\mathrm{r}_{\mathrm{syn}}+\mathrm{r}_{\text {decay }}=-\mathrm{Yr}_{\mathrm{HNTA}}-\mathrm{bX} & \text { rate of biomass accumulation } \\
\mathrm{r}_{\mathrm{O}_{2}}=1.59 \mathrm{r}_{\mathrm{HNTA}}+5 \mathrm{bX} & \text { rate of oxygen utilization } \\
\mathrm{r}_{\mathrm{H}^{-}}=2.42 \mathrm{r}_{\mathrm{HNTA}}+1 \mathrm{bX} & \text { rate of acidic hydrogen utilization } \\
\mathrm{r}_{\mathrm{H}_{2} \mathrm{CO}_{3}^{*}}=3.09 \mathrm{r}_{\mathrm{HNTA}}+5 \mathrm{bX} & \text { rate of } \mathrm{H}_{2} \mathrm{CO}_{3}^{*} \text { production } \\
\mathrm{r}_{\mathrm{NH}_{2}^{-}}=0.42 \mathrm{r}_{\mathrm{HNTA}_{\mathrm{A}}}+1 \mathrm{bX} & \text { rate of } \mathrm{NH}_{+}^{+} \text {production }
\end{array}
$$

where $\mathrm{q}_{\mathrm{ind}}$ is the maximum specific utilization rate for the electron donor substrate; $\mathrm{K}_{\mathrm{HNTA}}$ is the half maximum rate concentration for the specific donor species; $\mathrm{S}_{\mathrm{HNTA}}$ is the electron donor substrate concentration: $\mathrm{K}_{\mathrm{O}_{2}}$ is the half maximum concentration for the electron acceptor, oxygen; $\mathrm{S}_{\mathrm{O}}$ is the oxygen concentration; $\mathrm{X}$ is the concentration of active biomass degrading the primary substrate: $Y$ is the true yield coefficient: and $b$ is the biomass decay constant. The first 
355 coefficient in each of the last four rate equations is calculated directly from HNTA $A^{2-}$ degradation 356 stoichiometry. For example, the rate of oxygen utilization is $0.0875 / 0.055=1.59$ moles of $\mathrm{O}_{2}$ 357 consumed per mole of $\mathrm{HNTA}^{2-}$ degraded. Similarly, the second coefficient can be derived from 358 stoichiometry representing the complete endogenous mineralization of cell biomass (28). Thus, 359 mineralization of one mole of biomass $\left(\mathrm{C}_{5} \mathrm{H}_{7} \mathrm{O}_{2} \mathrm{~N}\right)$ consumes 5 moles of $\mathrm{O}_{2}$ and 1 mole of $\mathrm{H}^{+}$, 360 and produces 5 and 1 mole(s) of carbonic acid and $\mathrm{NH}_{4}{ }^{+}$, respectively. As $\mathrm{HNTA}^{2-}$ and acidic hydrogen are removed from the system, $\mathrm{H}_{2} \mathrm{CO}_{3}{ }^{*}$ and $\mathrm{NH}_{4}{ }^{+}$are 362 produced. To maintain chemical equilibrium, the remaining NTA re-equilibrates among its various acid-base and complex species based on the new $\mathrm{pH}$ and component totals. Initially, the presence of excess NTA in the system dominates neptunium speciation. However, eventually enough HNTA ${ }^{2-}$ is degraded that the total amount of NTA remaining in solution is no longer sufficient to complex most of the neptunium. The fate of the "free" neptunium then depends on the $\mathrm{pH}$ and presence of other ligands in solution.

In order to calculate the dominant neptunium speciation in the NTA growth medium, we considered the formation of 47 complexes from 16 components. The important neptunium aqueous species and their formation constants are shown in Table A-1. Formation constants for non-actinide metal complexes and acid dissociation constants were taken from Morel and Hering (21) and corrected to $0.1 \mathrm{M}$ ionic strength. Carbonate speciation was calculated by assuming Henry's Law equilibrium between the aqueous and gas phase $\mathrm{CO}_{2}$ concentrations. 
374

375

376

377

378

379

380

\section{REFERENCES}

1.Babich, H., and G. Stotzky. 1983. Toxicity of Nickel to Microbes: Environmental Aspects, p. 195-265. In A.I. Laskin (ed.). Advances in Applied Microbiology, vol. 29. Academic Press, New York.

2.Bidoglio, G., G. Tanet, and A. Chatt. 1985. Studies on Neptunium(V) Carbonate Complexes under Geologic Repository Conditions. Radiochimica Acta. 38:21-26.

3.Bolton, H. J., D. Girvin, A. Plymale, S. Harvey, and D. Workman. 1996. Degradation of Metal-Nitrilotriacetate Complexes by Chelatobacter heintzii. Environmental Science and Technology. 30(3):931-938.

4.Broido, M. S. 1995. Natural and Accelerated Bioremediation Research (NABIR). Program Plan DOE/ER-0659T. U. S. Department of Energy.

5.Clark, D. L., D. E. Hobart, and M. P. Neu. 1995. Actinide Carbonate Complexes and Their Importance in Actinide Environmental Chemistry. Chemical Reviews. 95:25-48.

6.Collins, Y., and G. Stotzky. 1989. Factors Affecting the Toxicity of Heavy Metals to Microbes, p. 31-90. In T. J. Beveridge and R. J. Doyle (ed.), Metal Ions and Bacteria. John Wiley and Sons, Inc, New York.

7.Eberle, S. H., and U. Wede. 1970. Chelatgleichgewichte Fünfwertiger Transurane mit Aminopolykarbonsäuren. Journal of Inorganic Nuclear Chemistry. 32:109-117.

8.Egli, T. 1994. Biochemistry and Physiology of the Degradation of Nitrilotriacetic Acid and other Metal Complexing Agents, p. 179-95. In C. Ratledge (ed.), Biochemistry of Microbial Degradation.

9.Ewing, D. 1987. Application of Radiation Chemistry to Studies in the Radiation Biology of Microorganisms, p. 501-526. In Farhataziz and M. A. J. Rodgers (ed.), Radiation Chemistry: Principles and Applications. VCH Publishers, New York.

10.Fahey, J. A. 1986. Neptunium, p. 443-498. In J. J. Katz, G. T. Seaborg, and L. R. Morss (ed.), The Chemistry of the Actinide Elements, 2nd ed, vol. 1. Chapman and Hall, New York. 
11.Francis, A. J.. G. A. Joshi-Topé, and C. Dodge. 1996. Metabolism of Nickel Citrate Complex and Modulation of Nickel Toxicity. Environmental Science and Technology. 30:562-568.

12.Lierse, C., W. Treiber, and J. I. Kim. 1985. Hydrolysis Reactions of Neptunium(V). Radiochimica Acta. 38:2728.

13.Lieser, K. H. 1995. Radionuclides in the Geosphere: Sources, Mobility, Reactions in Natural Waters and Interactions with Solids. Radiochimica Acta. 70/71:355-375.

14.Macaskie, L. E., R. M. Empson, F. Lin, and M. R. Tolleys. 1995. Enzymatically-Mediated Uranium Accumulation and Uranium Recovery Using a Citrobacter sp Immobilised as a Biofilm Within a Plug-Flow Reactor. Journal of Chemical Technology and Biotechnology. 63:1-16.

15.Macaskie, L. E., B. C. Jeong, and M. R. Tolley. 1994. Enzymically Accelerated Biomineralization of Heavy Metals: Application to the Removal of Americium and Plutonium from Aqueous Flows. FEMS Microbiology Reviews. 14:351-368.

16.Macaskie, L. E., J. R. Lloyd, R. A. P. Thomas, and M. R. Tolley. 1996. The Use of Microorganisms for the Remediation of Solutions Contaminated with Actinide Elements, Other Radionuclides, and Organic Contaminants Generated by Nuclear Fuel Cycle Activities. Nuclear Energy-Journal of the British Nuclear Energy Society. 35(4):257-271.

17.Markich, S. J., P. L. Brown, and R. A. Jeffree. 1996. The Use of Geochemical Speciation Modelling to Predict the Impact of Uranium to Freshwater Biota. Radiochimica Acta. 74:321-326.

18.Mattimore, V., K. S. Lidupa, G. A. Berne, and J. R. Battista. 1995. Genetic Characterization of Forty Ionizing Radiation-Sensitive Strains of Deinococcus radiodurans: Linkage Information from Transformation. Journal of Bacteriology. 177(18):5232-5237.

19.McCarty, P. L. 1972. Presented at the Proceedings: The International Conference Toward a Unified Concept of Biological Waste Treatment Design, Atlanta, GA, Oct 6, 1972. 
419 20.Means, J. L., D. A. Crerar, and J. O. Duguid. 1978. Migration of Radioactive Wastes: Radionuclide Mobilization by Complexing Agents. Science. 200(30 June):1+77-1481.

21.Morel, F. M. M., and J. G. Hering. 1993. Principles and Applications of Aquatic Chemistry. John Wiley \& Sons, New York.

22.Morgenstern, A., and J. I. Kim. 1996. The Phosphate Complexation of Neptunium(V). Radiochimica Acta. 72:73-77.

23.Neck, V., J. I. Kim, and B. Kanellakopulos. 1992. Solubility and Hydrolysis Behaviour of Neptunium(V). Radiochimica Acta. 56:25-30.

24.Neck, V., W. Runde, J. I. Kim, and B. Kanellakopulos. 1994. Solid Liquid Equilibrium Reactions of Neptunium(V) in Carbonate Solutions at Different Ionic Strength. Radiochimica Acta. 65(1):29-37.

25.Nitsche, H., and K. Becraft. 1992. The Complexation Behavior of Neptunium and Plutonium with Nitrilotriacetic Acid, p. 276-287. In L. R. Morss and J. Fuger (ed.), Tranuranium Elements - A Half Century. American Chemical Society, Washington, DC.

26.Reed, D. T. In preparation. Radiotoxicity of Plutonium Towards Chelatobacter heintzii. .

27.Riley, R. G., J. M. Zachara, and F. J. Wobber. 1992. Chemical Contaminants on DOE lands and Selection of Contaminant Mixtures for Subsurface Science Research DOE/ER-0547T. Office of Energy Research, U S Department of Energy.

28.Rittmann, B. E., and J. M. VanBriesen. 1996. Microbiological Processes in Reactive Transport Modeling, p. 311-334. In P. C. Lichtner, C. I. Steefel, and E. H. Oelkers. (ed.), Reviews in Mineralogy, vol. 34: Reactive Transport in Porous Media. Mineralogical Society of America.

29.Silva, R. J., and H. Nitsche. 1995. Actinide Environmental Chemistry. Radiochimica Acta. 70/71:377-396.

30.Stumm, W., and J. J. Morgan. 1996. Aquatic Chemistry, 3rd ed. John Wiley \& Sons, Inc., New York.

31.Tiedje, J. M., B. B. Mason, C. B. Warren, and E. J. Malec. 1973. Metabolism of Nitrilotriacetate by Cells of Pseudomonas sp. Applied Microbiology. 25(5):811-818. 
443 32.Weger, H. T. 1994. Ph.D. University of Illinois, Urbana-Champaign.

$4+4$ 33.Weger, H. T., S. Okajima, J. C. Cunnane, and D. T. Reed. Accepted. Bulk Solubility and Speciation of $445 \quad$ Plutonium(VI) in Phosphate-Containing Solutions. Inorganica Chimica Acta.

446 34.Wildung, R. E., and T. R. Garland. 1982. Effects of Plutonium on Soil Microorganisms. Applied and 447 Environmental Microbiology. 43:418-423. 
$4+8$ TABLE 1. Initial cell inoculations and total neptunium concentrations for neptunium-glucose and neptunium-NTA studies ${ }^{\mathrm{a}}$

\begin{tabular}{ccc}
\hline Experimental Code & $\begin{array}{c}\text { Total Neptunium } \\
(\mathrm{M})\end{array}$ & $\begin{array}{c}\text { Initial Cell Concentration } \\
\text { OD }_{600}\end{array}$ \\
\hline $1-\mathrm{B}-1$ & 0 & 0.004 \\
$1-\mathrm{B}-2$ & 0 & 0.004 \\
$1-\mathrm{B}-3$ & 0 & 0.004 \\
$1-9-1$ & $2.0 \times 10^{-8}$ & 0.004 \\
$1-8-1$ & $1.7 \times 10^{-8}$ & 0.004 \\
$1-7-1$ & $2.0 \times 10^{-7}$ & 0.004 \\
$1-6-1$ & $1.7 \times 10^{-6}$ & 0.004 \\
$1-5-1$ & $1.9 \times 10^{-5}$ & 0.004 \\
$1-4-1$ & $1.2 \times 10^{-4}$ & 0.004 \\
$1-4-2$ & $1.2 \times 10^{-4}$ & 0.004 \\
$2-\mathrm{B}-1$ & 0 & 0.007 \\
$2-\mathrm{B}-2$ & 0 & 0.007 \\
$2-\mathrm{B}-3$ & 0 & 0.059 \\
$2-\mathrm{B}-4$ & 0 & 0.007 \\
$2-\mathrm{B}-5$ & 0 & 0.059 \\
$2-4-1$ & $5.4 \times 10^{-5}$ & 0.007 \\
$2-4-2$ & $5.4 \times 10^{-5}$ & 0.007 \\
$2-4-3$ & $5.4 \times 10^{-5}$ & 0.059 \\
$2-4-4$ & $2.9 \times 10^{-4}$ & 0.007 \\
$2-4-5$ & $2.7 \times 10^{-4}$ & 0.059 \\
$2-4-\mathrm{B}$ & $5.4 \times 10^{-5}$ & 0.0 \\
$2-6-1$ & $5.9 \times 10^{-6}$ & 0.007 \\
$2-8-1$ & $6.0 \times 10^{-8}$ & 0.007 \\
\hline
\end{tabular}

450

451 Labels starting with 1 denote NTA mineral media. Label 2 represents minimal

452 glucose media. Initial NTA and glucose concentrations were $5.2 \mathrm{mM}(0.375 \mathrm{gm}$ 453 Chiter). 
454 TABLE 2. Final NTA and neptunium concentrations of filtered NTA

+55 growth medium samples after $\mathbf{4 8}$ days $^{\mathrm{a}}$

\begin{tabular}{cccc}
\hline Sample & Final $\mathbf{N p}(\mathbf{V})$ Concentration $(\mathbf{M})$ & Final NTA Concentration (M) & Final pH \\
\hline $\mathbf{1 - 4 - 1}$ & $3.84 \times 10^{-6}$ & $1.04 \times 10^{-6}$ & $7.90 \pm .03$ \\
$\mathbf{1 - 4 - 2}$ & $6.37 \times 10^{-6}$ & $2.91 \times 10^{-6}$ & $7.98 \pm .04$ \\
$\mathbf{1 - 5}-\mathbf{1}$ & $8.27 \times 10^{-6}$ & $\mathrm{ND}^{\mathrm{b}}$ & $7.83 \pm .03$ \\
$\mathbf{1 - 6 - 1}$ & $7.68 \times 10^{-7}$ & $\mathrm{ND}$ & $7.87 \pm .04$ \\
$\mathbf{1 - 7 - 1}$ & $1.52 \times 10^{-7}$ & $\mathrm{ND}$ & $7.73 \pm .03$ \\
$\mathbf{1 - 8 - 1}$ & $1.7 \times 10^{-8}$ & $7.97 \times 10^{-7}$ & $7.63 \pm .03$ \\
$\mathbf{1 - 9 - 1}$ & $2.0 \times 10^{-9}$ & $\mathrm{ND}$ & $7.84 \pm .02$ \\
\hline
\end{tabular}

${ }^{a}$ NTA concentrations determined by IC analysis. Neptunium determined by alpha particle

457 scintillation counting.

$458 \quad{ }^{b} \mathrm{ND}$ - Not Detected $\left(<1 \times 10^{-7} \mathrm{M}\right)$ 
TABLE A-1. Equilibrium formation constants for major neptunium aqueous species in NTA mineral growth medium

\begin{tabular}{lll}
\hline \multicolumn{1}{c}{ Species } & \multicolumn{1}{c}{$\beta_{\mathrm{xyz}}{ }^{\mathrm{a}}$} & References \\
\hline $\mathrm{NpO}_{2} \mathrm{OH}$ & $\beta_{1(-1) 0}=10^{-11.3}$ & $(12,23)$ \\
$\mathrm{NpO}_{2}(\mathrm{OH})_{2}^{-}$ & $\beta_{1(-2) 0}=10^{-23.43}$ & $(12,23)$ \\
$\mathrm{NpO}_{2} \mathrm{CO}_{3}^{-}$ & $\beta_{101}=10^{4.38}$ & $(2,5,24)$ \\
$\mathrm{NpO}_{2}\left(\mathrm{CO}_{3}\right)_{2}{ }^{3-}$ & $\beta_{102}=10^{6.55}$ & $(2,5,24)$ \\
$\mathrm{NpO}_{2}\left(\mathrm{CO}_{3}\right)_{3}^{5-}$ & $\beta_{103}=10^{6.4}$ & $(2,5,24)$ \\
$\mathrm{NpO}_{2} \mathrm{NTA}^{2-}$ & $\beta_{101}=10^{6.80}$ & $(7,25)$ \\
$\mathrm{NpO}_{2} \mathrm{HNTA}^{-}$ & $\beta_{111}=10^{1.77}$ & $(7)$ \\
$\mathrm{NpO}_{2}\left(\mathrm{OH}^{2-}\right)^{2}{ }^{2-}$ & $\beta_{1(-1) 1}=10^{-4.66}$ & $(7)$ \\
$\mathrm{NpO}_{2} \mathrm{HPO}_{4}^{-}$ & $\beta_{111}=10^{14.23}$ & $(22)$ \\
$\mathrm{NpO}_{2} \mathrm{PO}_{4}{ }^{2-}$ & $\beta_{101}=10^{6.33}$ & $(22)$ \\
\hline
\end{tabular}

$461{ }^{a}$ Where $\beta_{x y z}=\frac{\left[M_{x} H_{y} L_{z}\right]}{[M]^{x}[H]^{y}[L]^{z}}$ or $\beta_{x(-y) z}=\frac{\left[M_{x}(O H)_{y} L_{z}\right][H]^{y}}{[M]^{x}[L]^{z}}$. 
462 FIG. 1. Growth of Chelatobacter heintzii in glucose media $\left(\mathrm{OD}_{600}\right)$ as a function of time for 463 growing (a) and resting (b) cells.

${ }_{46+} \quad$ FIG. 2. $\mathrm{NpO}_{2}^{+}$concentration, determined by VIS-NIR absorption spectrometry, as a 465 function of time $(\varepsilon=392 @ 980.2 \mathrm{~nm})$. The free ion concentration remained stable over the 466 course of the experiment, indicating no change in oxidation state or complexation occurred 467 during glucose degradation by $C$. heintzii.

468 FIG. 3. Growth of $C$. heintzii vs time in NTA mineral media. Error bars are $99 \%$ 469 confidence limits of the mean of three blank samples.

470 FIG. 4. Neptunium partitioning during NTA degradation by $C$. heintzii. Partitioning was 471 determined by alpha particle scintillation count comparison of filtered to unfiltered 472 samples.

FIG. 5. Percent particulate neptunium as a function of total neptunium concentration at the end of the experiment. Dashed lines represent $95 \%$ confidence interval. $\mathrm{Np}(\mathrm{V})$ partitioning with the solid phase was proportional to the total neptunium concentration. degradation by $C$. heintzii, showing both the stability of the neptunium-NTA complex $\left(990.2 \mathrm{~nm}\right.$ peak), and microbial growth $\left(\mathrm{OD}_{600}\right)$. After NTA degradation, neptunium speciation shifted to the phosphate system, indicated by the $1015 \mathrm{~nm}$ absorption band. 
480 FIG. 7. Enlargement of the 970 to $1050 \mathrm{~nm}$ region of the unfiltered 48 day spectrum 481 shown in FIG. 6. The $1015 \mathrm{~nm}$ peak is clearly visible. A small amount of neptunium-NTA 482 complex was seen after filtration ( $990 \mathrm{~nm}$ peak, inset).

483

FIG. 8. Neptunium speciation during NTA degradation for $0.125 \mathrm{mM} \mathrm{Np}(\mathrm{V})$ in NTA mineral growth media, calculated by the dynamic chemical equilibrium computer code, CCBATCH. Calculations are based on equilibrium with $10^{-2.7}$ atm $\mathrm{CO}_{2}(\mathrm{~g})$ partial pressure and the assumption that no solid phases are present.

FIG. 9. Calculated dominant neptunium complexes in the mineral growth medium as a function of amount of NTA degraded, under the same conditions noted in Figure 8. $\mathrm{NpO}_{2} \mathrm{HPO}_{4}^{-}$and $\mathrm{NpO}_{2} \mathrm{PO}_{4}^{2-}$ are the dominant neptunium species following NTA degradation, accounting for $80 \%$ of the total neptunium. The $\mathrm{NpO}_{2} \mathrm{CO}_{3}{ }^{-}$species accounted for less than $10 \%$ of the total neptunium in solution after NTA degradation.

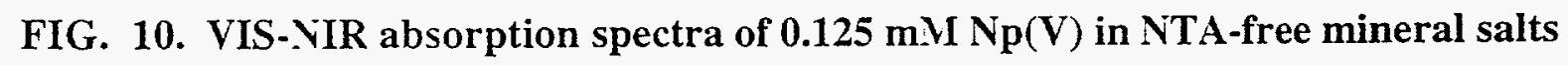
growth media at various $\mathrm{pH}$. The dominant neptunium species in solution are $\mathrm{NpO}_{2}{ }^{+}$ $(980.2 \mathrm{~nm}(10)), \mathrm{NpO}_{2} \mathrm{HPO}_{4}{ }^{-}(988.8 \mathrm{~nm}(22))$, and $\mathrm{NpO}_{2} \mathrm{PO}_{4}{ }^{2 \cdot}(993.6 \mathrm{~nm}(22))$. Spectra matched those obtained for a $20 \mathrm{mM} \mathrm{H}_{3} \mathrm{PO}_{4}$ solution (not shown).

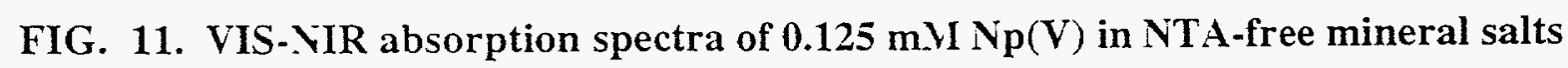
growth media at $\mathrm{pH} 7.87(\mathrm{a})$, and in a $20 \mathrm{mM} \mathrm{H}_{3} \mathrm{PO}_{4}$ solution at $\mathrm{pH} 8.22$ (b), both as a function of time. Predominant neptunium speciation shifts from phosphate complexation to an unidentified colloidal/precipitate phase $(1015 \mathrm{~nm})$. Note the increase in solution turbidity (baseline $O D_{960}$ shift from 0.011 to 0.031 ) caused by agitation. 
501 FIG. 12. VIS-NIR absorption spectra of $0.125 \mathrm{mM} \mathrm{Np}(\mathrm{V})$ in NTA-free mineral salts 502 growth media at $\mathrm{pH} 7.87$ after 3 days (a), and in a $20 \mathrm{mM} \mathrm{H3PO} 4$ solution at $\mathrm{pH} 8.22$ after 5031 day (b). The neptunium-phosphate colloidal/precipitate phase (1015 nm) remained 504 stable. Once again, agitation increased the turbidity of the solution. 

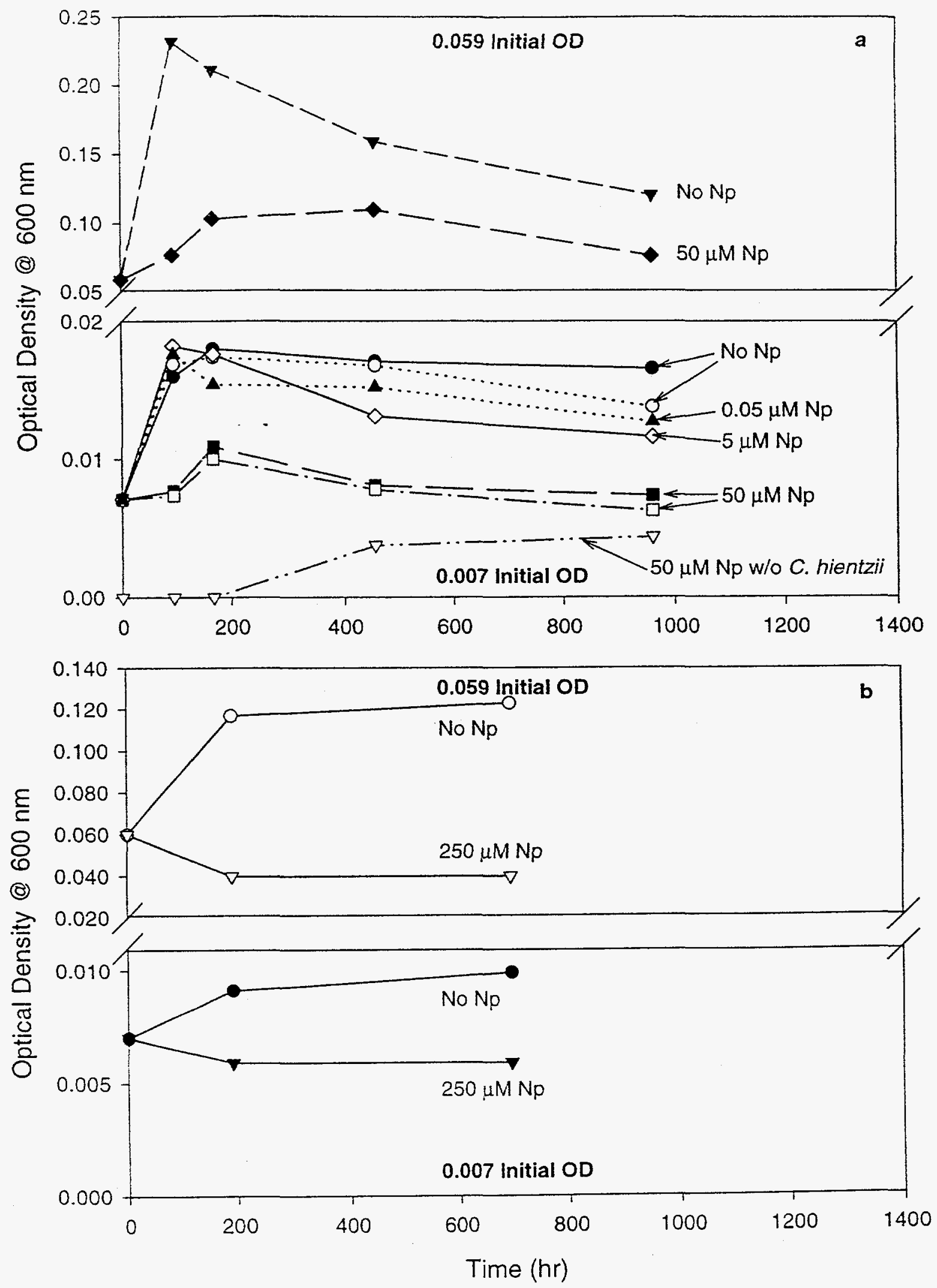

Figure 1 - Growth of Chelatobacter heintzii in glucose media $\left(O D_{600}\right)$ as a function of time for growing (a) and resting (b) cells. 


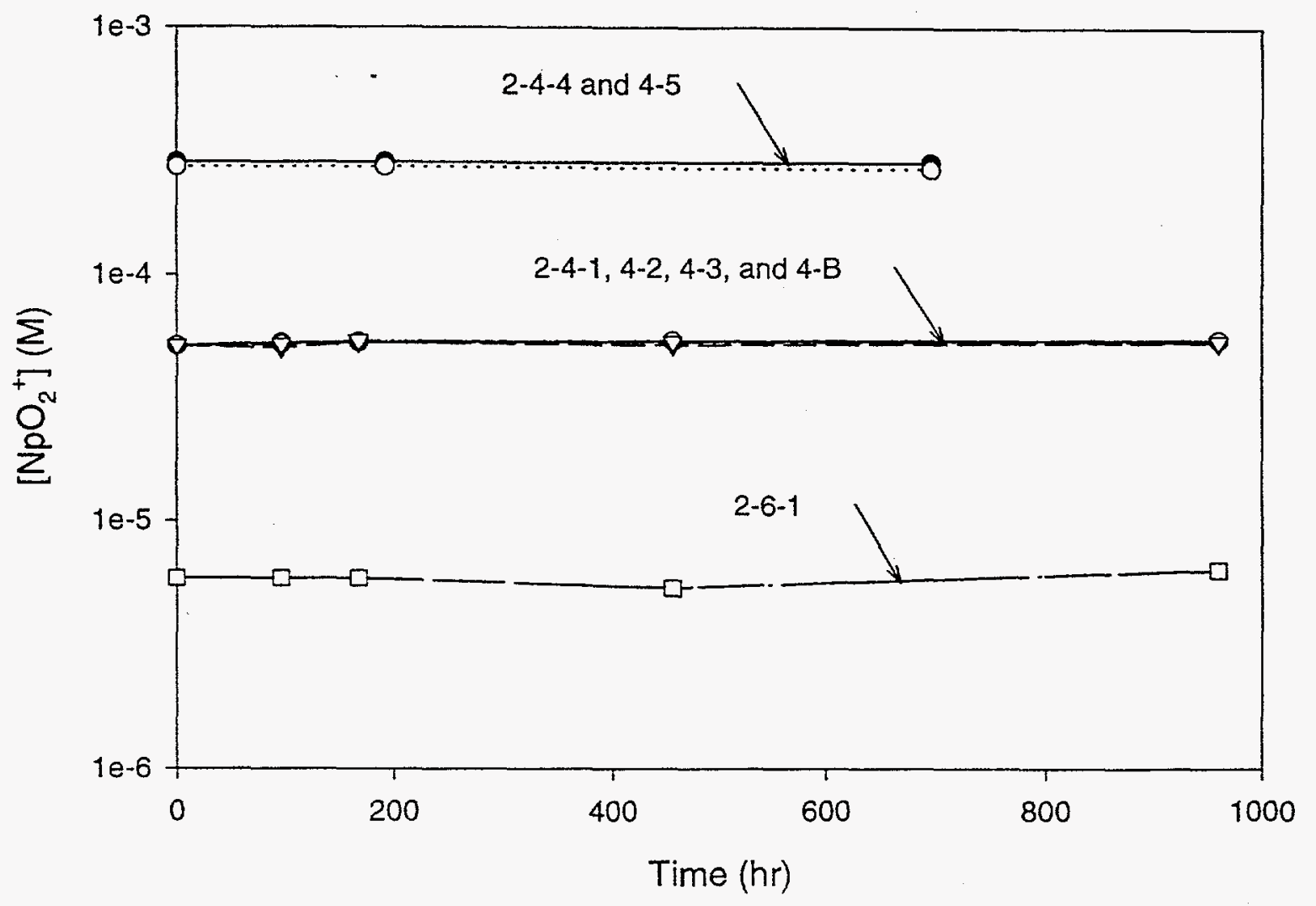

Figure $2-\mathrm{NpO}_{2}{ }^{+}$concentration as determined by VIS-NIR absorption spectrometry as a function of time $(e=392 @ 980.2 \mathrm{~nm})$. The free ion concentration remained stable over the course of the experiment, indicating no change in oxidation state or complexation occurred during glucose degradation by $C$. heintzii. 


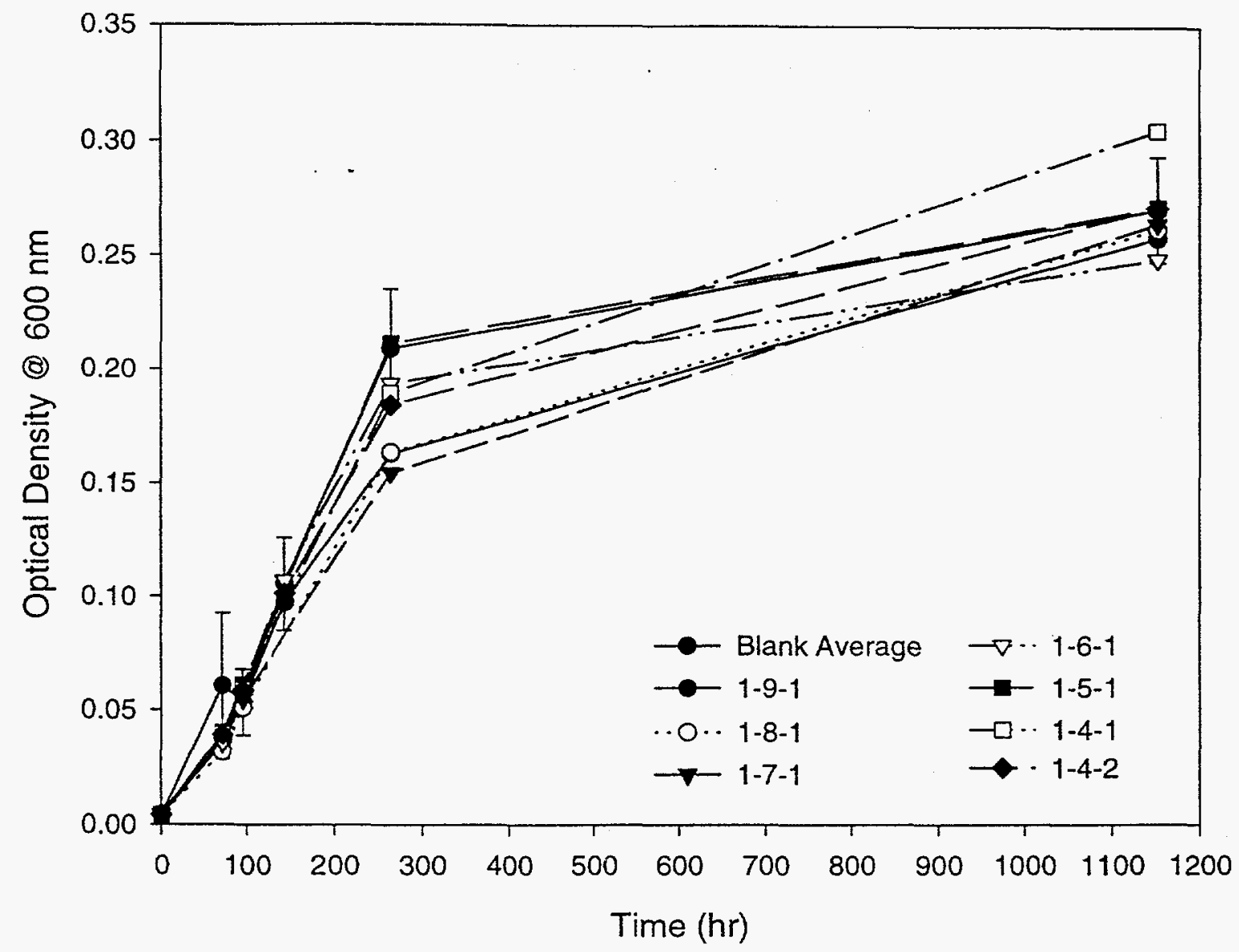

Figure 3 - Growth of $C$. heintzii vs time in NTA mineral media. Error bars are $99 \%$ confidence limits of the mean of three blank samples. 


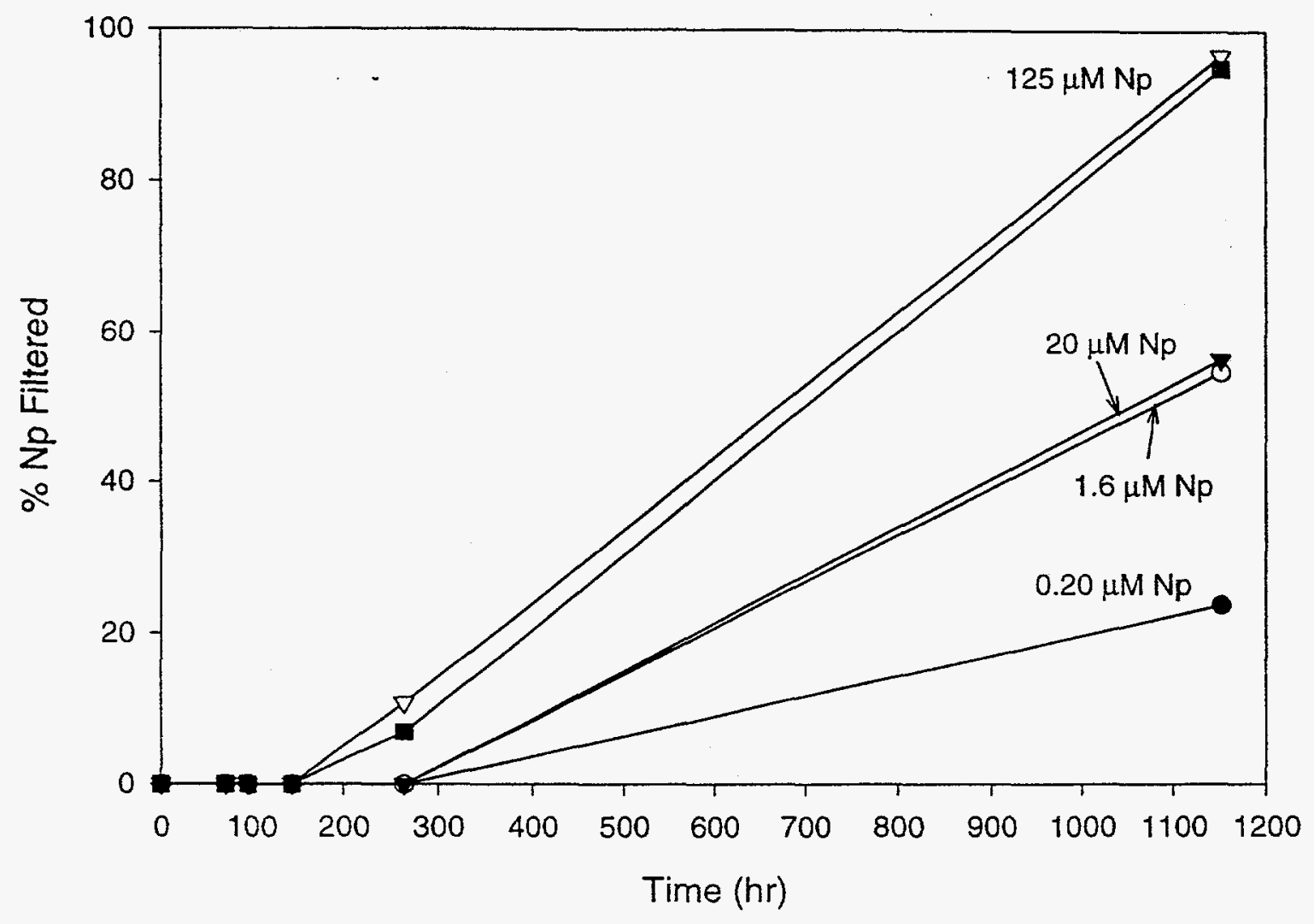

Figure 4 - Neptunium partitioning during NTA degradation by $C$. heintzil. Partitioning was determined by alpha particle scintillation count comparison of filtered to unfiltered samples. 


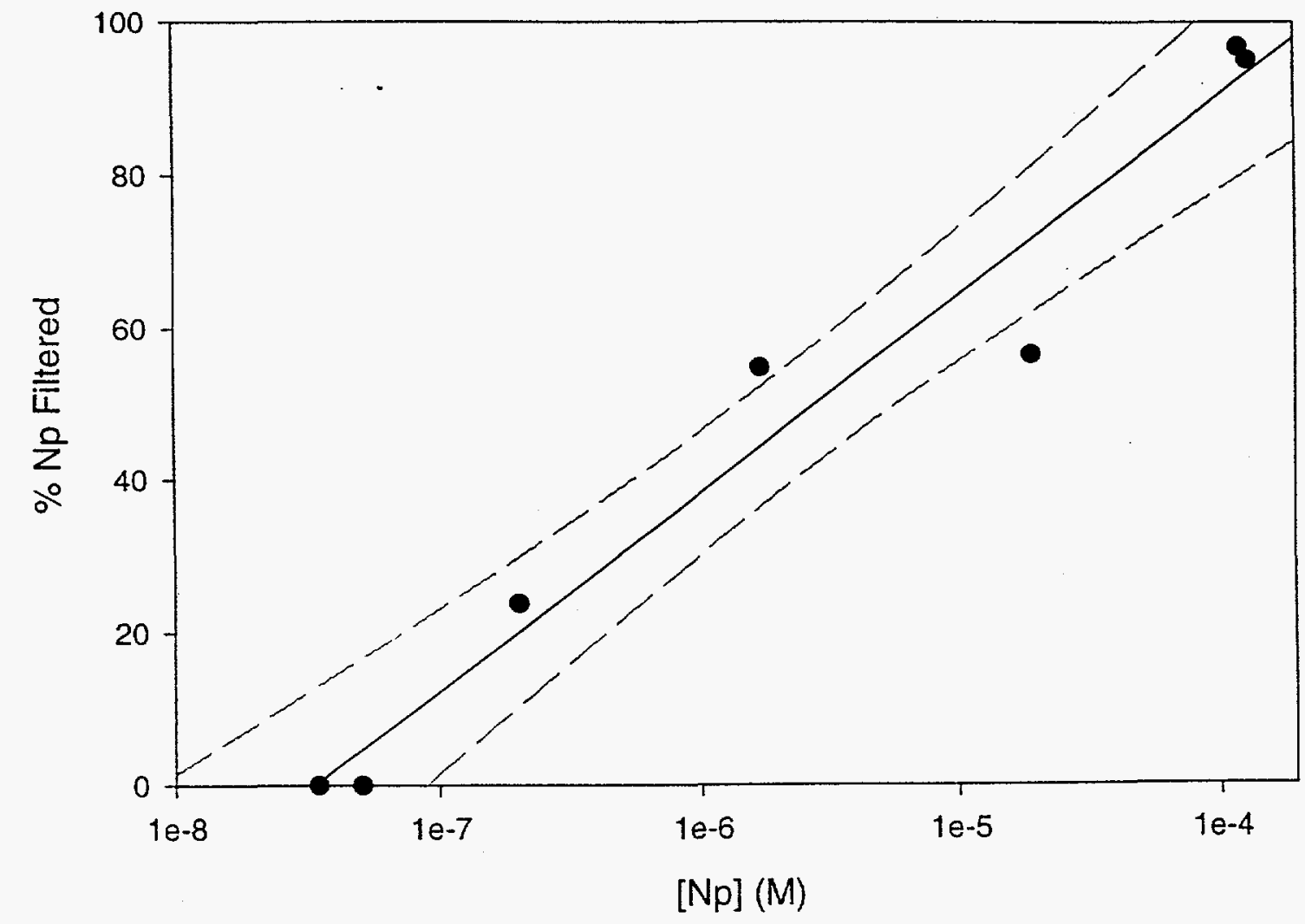

Figure 5 - Percent particulate neptunium as a function of total $\mathrm{Np}$ concentration at the end of the experiment. Dashed lines represent 95\% confidence interval. $\mathrm{Np}(\mathrm{V})$ partitioning with the solid phase was proportional to the total $\mathrm{Np}$ concentration. 


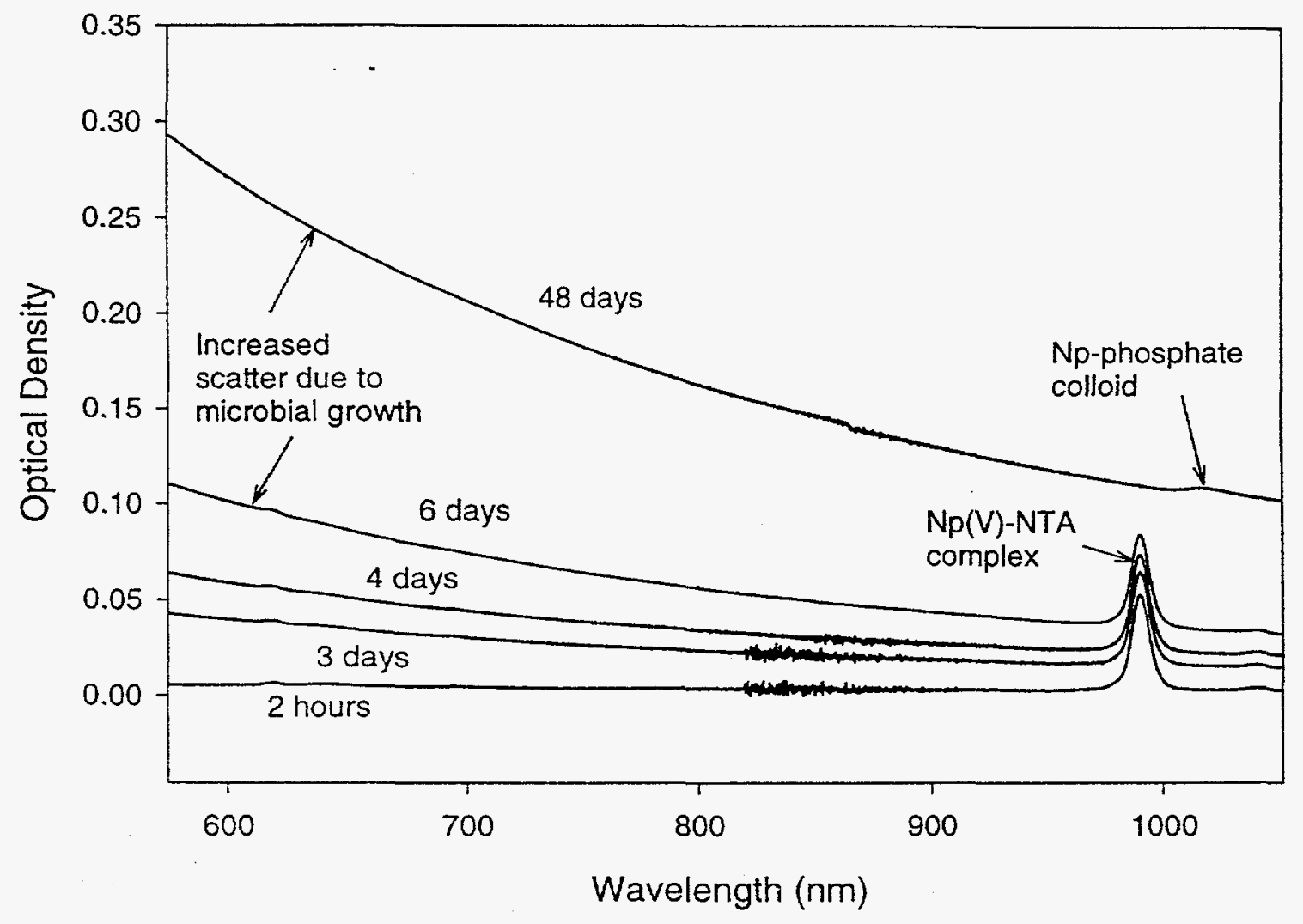

Figure 6 - VIS-NIR spectra of $1.25 \times 10^{-4} \mathrm{M} \mathrm{Np}$ in NTA mineral media during NTA degradation by $C$. heintzii, showing both the stability of the Np-NTA complex (990.2 nm peak), and microbial growth $\left(O D_{600}\right)$. After NTA degradation, Np speciation shifted to the phosphate system, indicated by the $1015 \mathrm{~nm}$ absorbance band. 


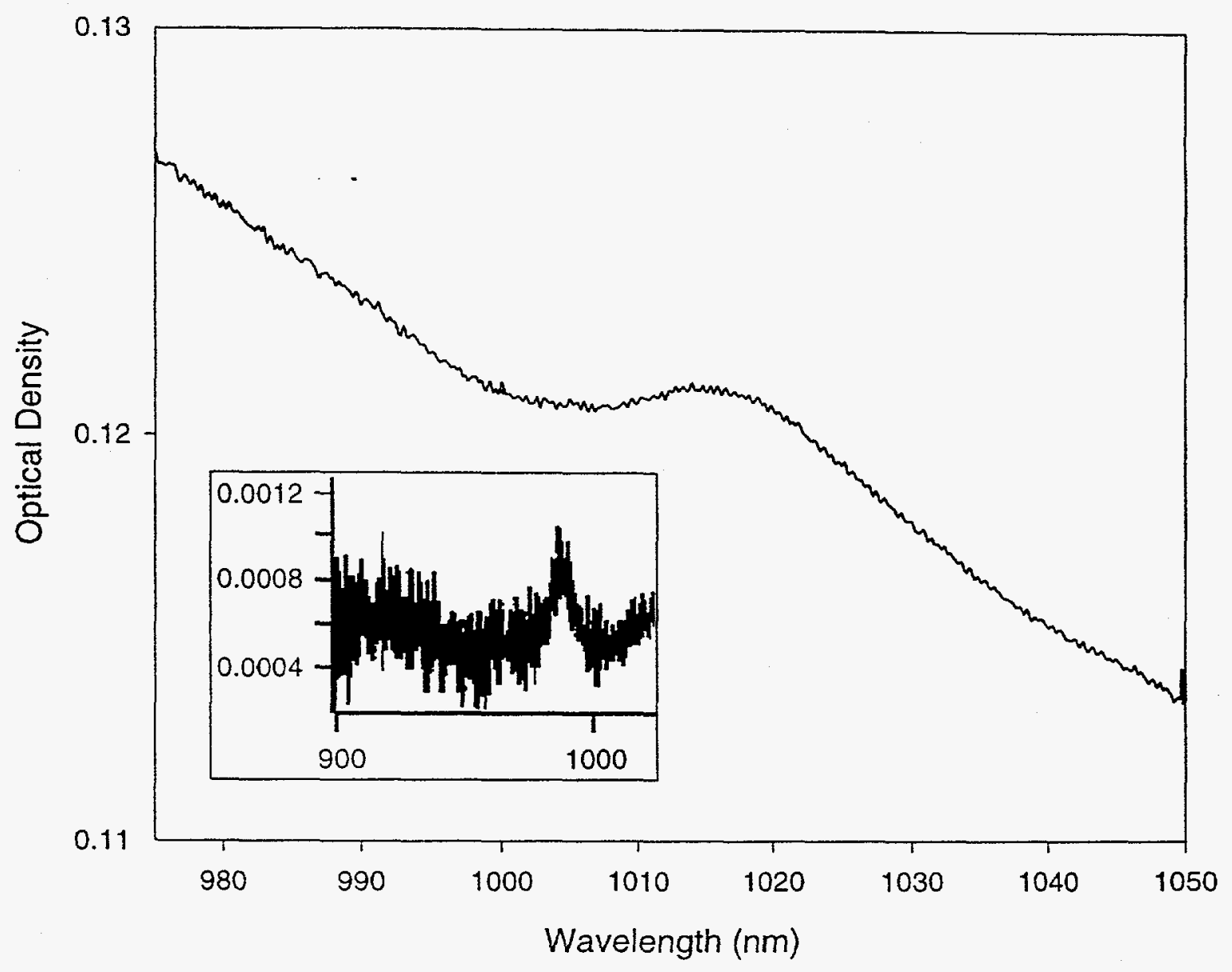

Figure 7 - Enlargement of the 970 to $1050 \mathrm{~nm}$ region of the unfiltered 48 day spectrum shown in Figure 6. The $1015 \mathrm{~nm}$ peak is clearly visible. A small amount of Np-NTA complex was seen after filtration (990 nm peak, inset). 


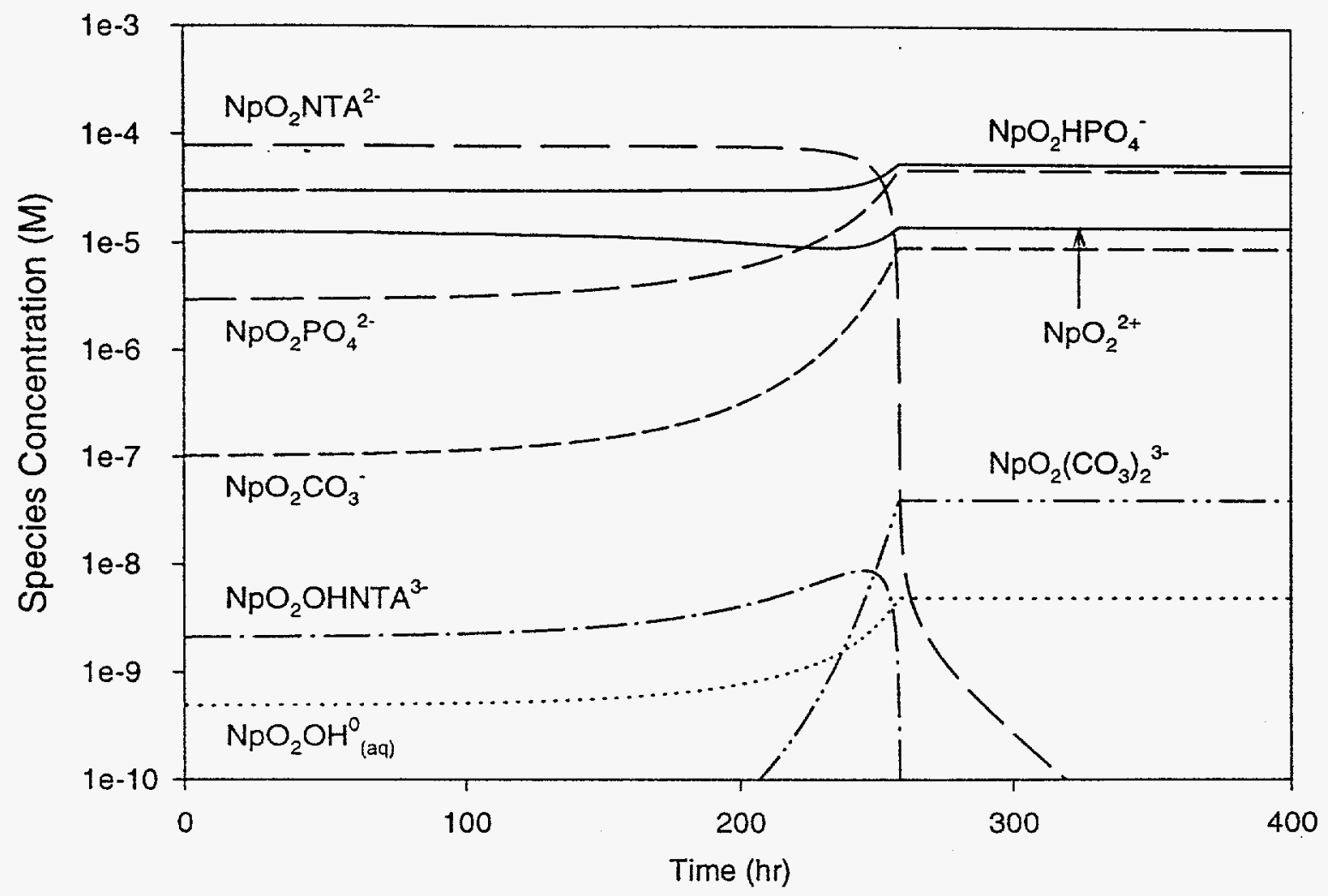

Figure 8 - Np speciation during NTA degradation for $0.125 \mathrm{mM} \mathrm{Np}(\mathrm{V})$ in NTA mineral growth media, calculated by the dynamic chemical equilibrium computer code, CCBATCH. Calculations are based on equilibrium with $10^{-2.7}$ atm $\mathrm{CO}_{2}(\mathrm{~g})$ partial pressure and the assumption that no solid phases are present. 


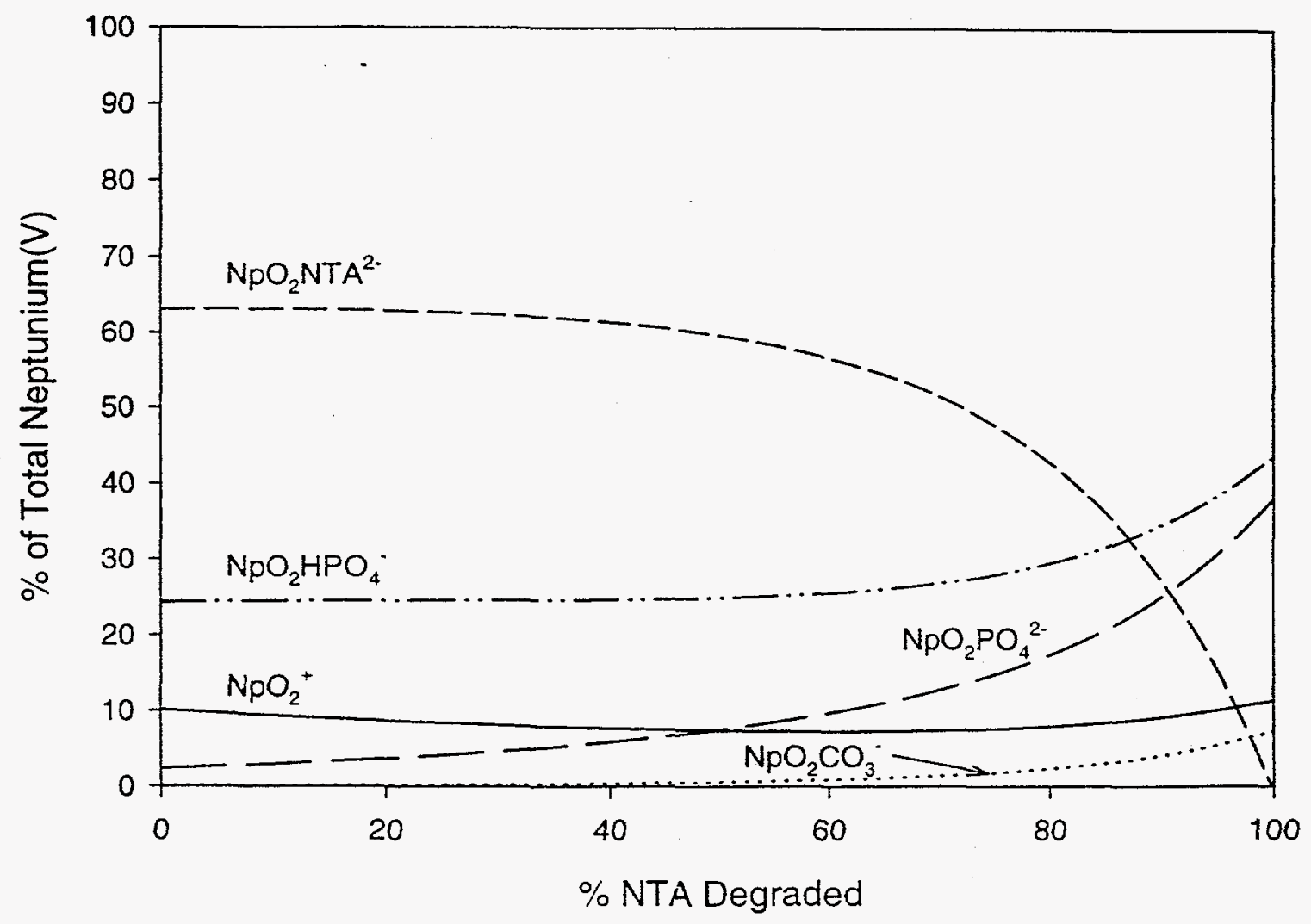

Figure 9 - Dominant Np complexes in the mineral growth medium as a function of the amount of NTA degraded, under the same conditions noted in Figure 8. $\mathrm{NpO}_{2} \mathrm{HPO}_{4}{ }_{4}$ and $\mathrm{NpO}_{2} \mathrm{PO}_{4}{ }^{2-}$ are the major $\mathrm{Np}$ species following NTA degradation, accounting for $80 \%$ of the total Np. The $\mathrm{NpO}_{2} \mathrm{CO}_{3}{ }^{-}$species accounted for less than $10 \%$ of the total $\mathrm{Np}$ in solution after NTA degradation. 


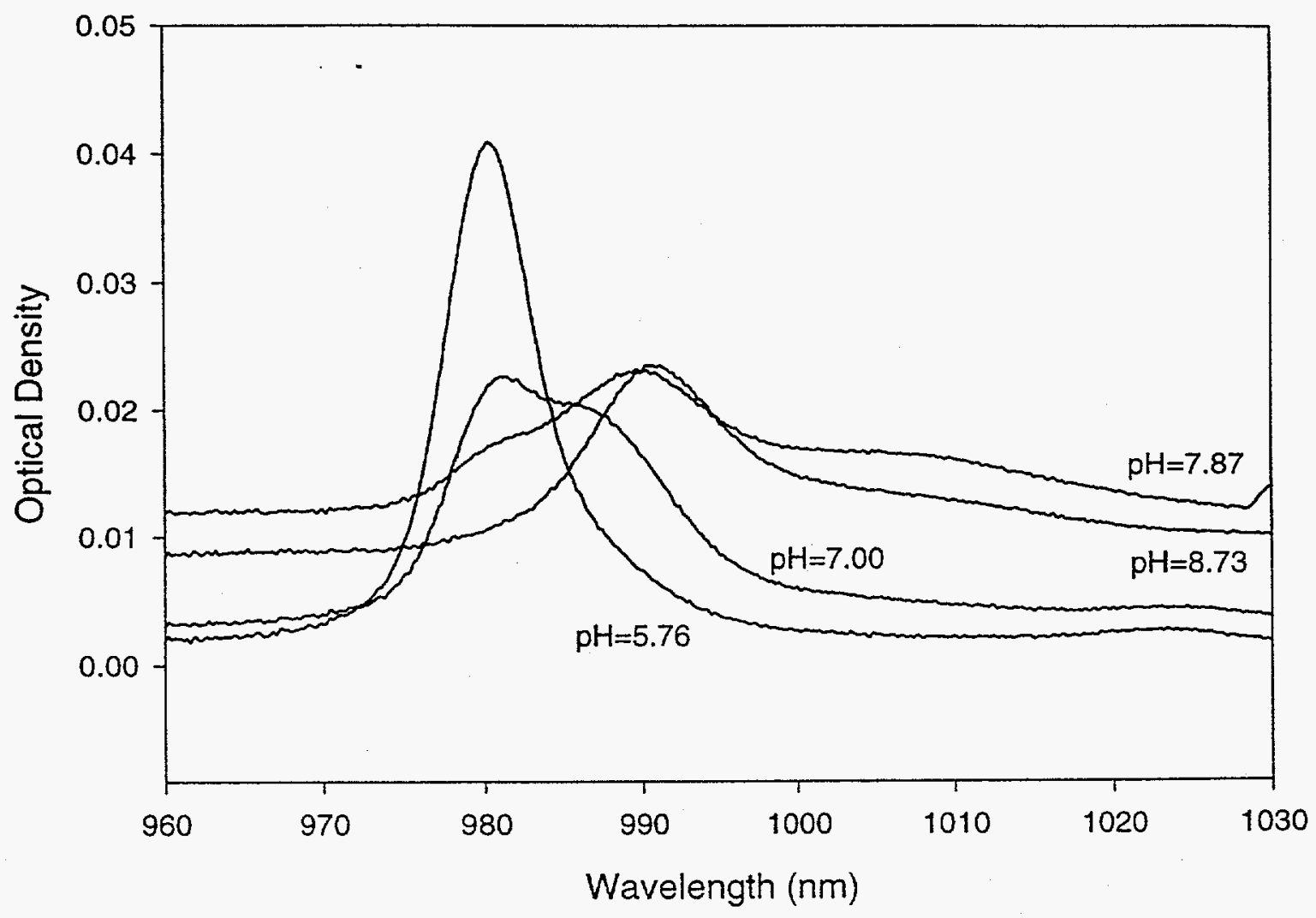

Figure 10 - VIS-NIR absorption spectra of $0.125 \mathrm{mM} \mathrm{Np(V)} \mathrm{in} \mathrm{NTA-free}$ mineral salts growth media at various $\mathrm{pH}$. The dominant $\mathrm{Np}$ species in solution are $\mathrm{NpO}_{2}{ }^{+}(980.2 \mathrm{~nm}(10)), \mathrm{NpO}_{2} \mathrm{HPO}_{4}{ }^{-}(988.8 \mathrm{~nm}(22))$, and $\mathrm{NpO}_{2} \mathrm{PO}_{4}{ }^{2-}(993.6 \mathrm{~nm}(22))$. Spectra matched those obtained for a 20 $\mathrm{mM} \mathrm{H}_{3} \mathrm{PO}_{4}$ solution (not shown). 

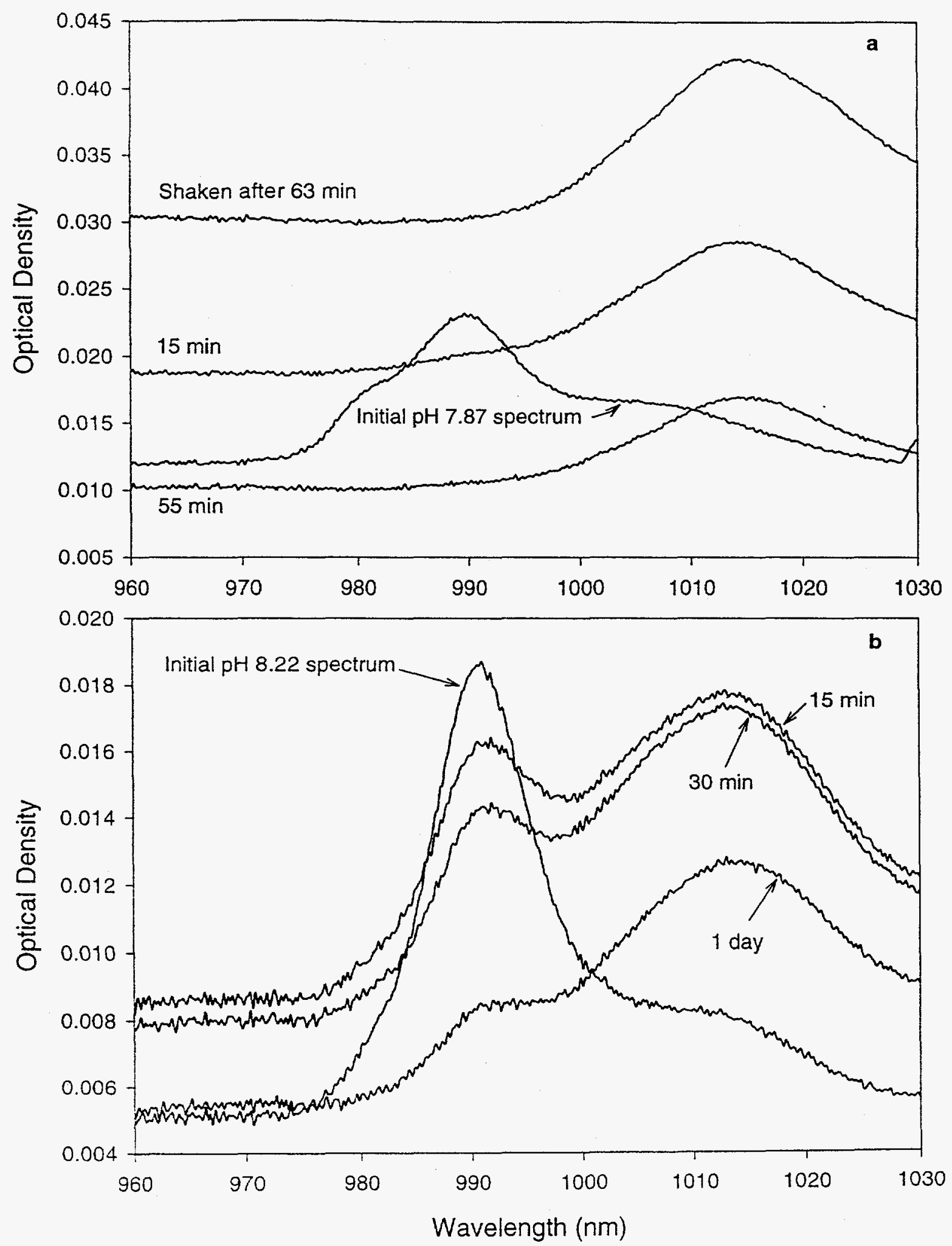

Figure 11 - VIS-NIR absorption spectra of $0.125 \mathrm{mM} \mathrm{Np}(\mathrm{V})$ in NTA-free mineral salts growth media at pH 7.87 (a), and in a $20 \mathrm{mM} \mathrm{H}_{3} \mathrm{PO}_{4}$ solution at $\mathrm{pH} 8.22$ (b), both as a function of time. Predominant $\mathrm{Np}$ speciation shifts from phosphate complexation to an unidentified colloidal/precipitate phase $(1015 \mathrm{~nm})$. Note the increase in solution turbidity (baseline $\mathrm{OD}_{960}$ shift from 0.011 to 0.031 ) caused by agitation. 

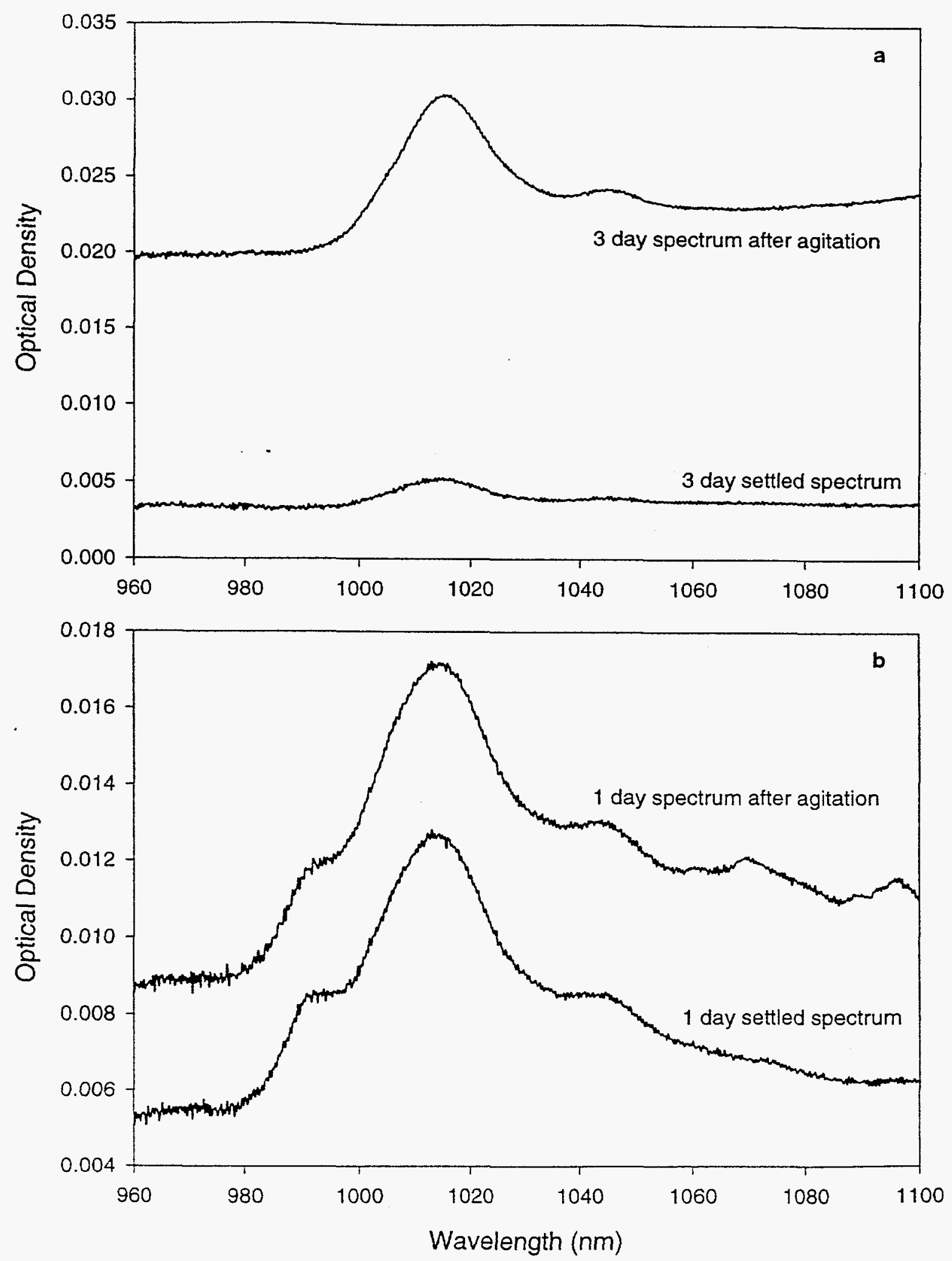

Figure 12 - VIS-NIR absorption spectra of $0.125 \mathrm{mM} \mathrm{Np}(\mathrm{V})$ in NTA-free mineral salts growth media at pH 7.87 after 3 days (a), and in a $20 \mathrm{mM}$ $\mathrm{H}_{3} \mathrm{PO}_{4}$ solution at $\mathrm{pH} 8.22$ after 1 day (b). The Np-phosphate colloidal/precipitate phase $(1015 \mathrm{~nm})$ remained stable. Once again, agitation increased the turbidity of the solution. 